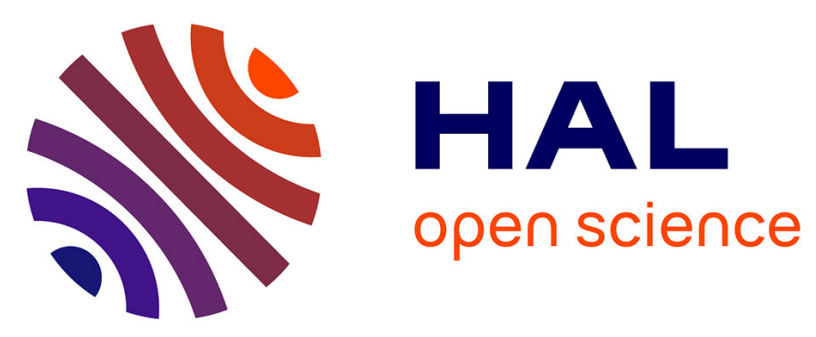

\title{
Consequences of trace metal cocktail exposure in zebra finch (Taeniopygia guttata) and effect of calcium supplementation
}

\author{
Agnès Saulnier, Josefa Bleu, Anne Boos, Islah El Masoudi, Pascale Ronot, \\ Sandrine Zahn, Mirella del Nero, Sylvie Massemin
}

\section{To cite this version:}

Agnès Saulnier, Josefa Bleu, Anne Boos, Islah El Masoudi, Pascale Ronot, et al.. Consequences of trace metal cocktail exposure in zebra finch (Taeniopygia guttata) and effect of calcium supplementation. Ecotoxicology and Environmental Safety, 2020, 193, pp.110357. 10.1016/j.ecoenv.2020.110357 . hal03102771

\section{HAL Id: hal-03102771 \\ https://hal.science/hal-03102771}

Submitted on 7 Jan 2021

HAL is a multi-disciplinary open access archive for the deposit and dissemination of scientific research documents, whether they are published or not. The documents may come from teaching and research institutions in France or abroad, or from public or private research centers.
L'archive ouverte pluridisciplinaire HAL, est destinée au dépôt et à la diffusion de documents scientifiques de niveau recherche, publiés ou non, émanant des établissements d'enseignement et de recherche français ou étrangers, des laboratoires publics ou privés. 
1 Consequences of trace metal cocktail exposure in zebra finch (Taeniopygia

Agnès Saulnier ${ }^{a, *}$, Josefa Bleu ${ }^{\mathrm{a}}$, Anne Boos ${ }^{\mathrm{a}}$, Islah El Masoudi ${ }^{\mathrm{a}}$, Pascale Ronot ${ }^{\mathrm{a}}$, Sandrine Zahn ${ }^{\mathrm{a}}$, Mireille Del Nero $^{\text {a }} \&$ Sylvie Massemin ${ }^{\mathrm{a}}$

${ }^{\text {a } U n i v e r s i t e ́ ~ d e ~ S t r a s b o u r g, ~ C N R S, ~ I P H C ~ U M R ~ 7178, ~ F-67000 ~ S t r a s b o u r g, ~ F r a n c e ~}$

*Corresponding author: Université de Strasbourg, CNRS, IPHC UMR 7178, 23 rue du Loess, F-67000 Strasbourg, France agnes.saulnier@iphc.cnrs.fr

8

9

\section{Abstract:}

Trace metal elements are significant stressors in urban areas. Their harmful effects on physiological parameters are demonstrated, but current laboratory studies are not representative of wild chronic exposure to a trace metal cocktail. Calcium can reduce the accumulation and toxicity of several metals, but soil acidification in cities leads to a decrease in bioavailability of this mineral. The objective of this study was to investigate the accumulation and toxicity of a trace metal cocktail representative of urban exposure on passerine birds, and test the importance of calcium availability on these toxic effects. We exposed zebra finches (Taeniopygia guttata) to a cocktail of seven metals and one metalloid in drinking water, with or without calcium supplementation. We monitored the concentration of metals in the blood and feathers, and their effects on oxidative status and telomere length. The metal cocktail led to higher concentration of all elements in the feathers, and of arsenic and lead in the blood. Birds with a higher concentration of cadmium, arsenic and lead in the feathers had shorter telomeres, but no impact of the cocktail was detected on oxidative status. Birds of the 'calcium' group and the 'calcium and metal' group accumulated higher concentrations of zinc, chromium and nickel in feathers. The 'calcium and metal' group also accumulated lower concentrations of arsenic and lead in feathers compared to the 'metal' group. Our results suggest that chronic exposure to a cocktail of metals at low concentrations has deleterious effects on birds, which can be limited through calcium intake.

Keywords: Urban pollution; oxidative stress; telomeres; metal toxicity; birds 
Trace metal elements (TME), including those commonly called 'heavy metals' by misuse of language (Duffus, $2002)$ in reference to their potential toxicity (e.g. lead $(\mathrm{Pb})$, cadmium $(\mathrm{Cd})$ ), are by definition naturally present in the environment in low concentration (under 1000 ppm in the earth's crust). However, anthropogenic activities such as the combustion of fossil fuels, road traffic or industry, lead to massive releases of these metals into the environment (Järup, 2003). These activities are mainly concentrated in urban areas, leading to higher levels of TME in cities than in natural habitats. Multiple studies in polluted areas revealed that TME-pollution at very high concentrations could be related to several damages to birds physiology, primarily oxidative balance (Berglund et al., 2014; Espín et al., 2017; Sánchez-Virosta et al., 2019). Chronic exposure to TME leads to their accumulation in different tissues such as the kidneys, liver, muscles, or for birds, in the feathers (Dauwe et al., 2005; Espín et al., 2016a). Accumulation can lead to the production of reactive oxygen species (ROS) via direct (Fenton) or indirect (mitochondria dysfunction) reactions (Koivula and Eeva, 2010; Leonard et al., 2004). In response to the production of ROS, the organism could increase the production of antioxidants such as enzymes and radical scavengers (Berglund et al., 2007; Rainio et al., 2015). Glutathione (GSH) is a major antioxidant in metal-related oxidative stress. GSH can reduce ROS, but can also chelate pro-oxidant metal ions through a reaction catalysed by glutathione peroxidase (GPx) to make them biologically inert and facilitate their elimination (Koivula and Eeva, 2010). Inversely, some metals, notably $\mathrm{Pb}$ and cadmium $\mathrm{Cd}$, can also deplete this antioxidant (Espín et al., 2014b; Fraga, 2005). Glutathione metabolism is a reliable marker of pollutant exposure in urban areas (Isaksson, 2010) and is frequently used as a metal-stress biomarker (Berglund et al., 2014; De la Casa-Resino et al., 2015; Espín et al., 2014a; Rainio et al., 2013). Non-neutralised ROS leads to oxidative stress and can cause macromolecular damage on proteins and lipids leading to the apparition of reactive oxygen metabolite (ROM), but also on DNA. In particular, it can lead to accelerated erosion of telomeres, which results in early ageing of organisms (Boonekamp et al., 2017; Epel et al., 2004). Stauffer et al. (2017) showed that great tits' nestlings (Parus major) living in a polluted environment had shorter telomeres than chicks living in an unpolluted environment. However, in urban environments, a previous study on the same species showed that telomere length is a predictor of birds' survival, with a selective disappearance of individuals who had shorter telomeres (Salmón et al., 2017). Yet, the correlation with metal exposure was not demonstrated.

Laboratory studies, in a controlled environment, are necessary to tease apart the effects of TME pollution on oxidative balance and telomere length. Laboratory studies have shown that the toxicity of metals are strongly regulated by competition processes between metals (Goyer, 1997; Levander, 1978; Wah Chu and Chow, 2002; Yenice et al., 2015). Some TME, such as zinc ( $\mathrm{Zn})$ and copper $(\mathrm{Cu})$, are crucial for biological processes and are therefore called 'essential'. Others, such as lead $(\mathrm{Pb})$ and mercury $(\mathrm{Hg})$, are non-essential to biological processes and are directly toxic to organisms. Antagonistic relationships between these two types of metals have been demonstrated. Essential TME can limit the accumulation and thereby, the deleterious effects of non-essential metals (Goyer, 1997; Levander, 1978). For example, Zn has an antagonistic impact on tissue accumulation and toxicity of $\mathrm{Pb}$ (Prasanthi et al., 2010). There may also be synergistic effects between metals, with increased toxicity of cocktail metals compared to the sum of the toxicities of each metal separately (Wah Chu and Chow, 2002). But only a few laboratory studies have been conducted on cocktails containing more than two metals (Stankevičiūtė et al., 2018; Wah Chu and Chow, 2002; Zhu et al., 2004) especially on a bird model (Scheuhammer, 1996; Yenice et al., 2015). However, in cities, animals are exposed to diffuse pollution, i.e. a cocktail of numerous TME at low 
concentration, containing essential and non-essential metals and metalloid. Also, exposure to TME is often associated with emissions of Sulphur dioxide $\left(\mathrm{SO}_{2}\right)$ and Nitrogen oxides (NOx) in urban areas, which leads to soil acidification and limits the bioavailability of essential elements such as calcium $(\mathrm{Ca})$ in the environment (Scheuhammer, 1991). Ca is crucial for reproduction in birds but is also known to limit the absorption and toxicity of some metals such as Pb or Cd (Eeva and Lehikoinen, 2004; Goyer, 1997). For example, Snoeijs et al. (2005) have shown that $\mathrm{Ca}$ supplementation in zebra finch resulted in lower $\mathrm{Pb}$ concentrations in the kidney and bones and prevented lead inhibition of second humoral responses. Several studies have also recently shown that Ca supplementation could increase the antioxidant capacity to cope with metal-related oxidative stress (Espín et al., 2016c; Sánchez-Virosta et al., 2019).

In this study, we propose to test the effects of a TME cocktail on the physiology of a bird species, the zebra finch (Taeniopygia guttata), and in addition, the impact of Ca supplementation on the harmful effects of TME. For this purpose, we exposed birds to a cocktail of 7 trace metals $(\mathrm{Cu}, \mathrm{Zn}, \mathrm{Pb}, \mathrm{Cd}$, chromium $(\mathrm{Cr})$, nickel (Ni) and cobalt (Co)) and 1 metalloid (arsenic (As)), whose concentrations are representative of exposure in a medium-sized city $\left(337.61 \mathrm{~km}^{2}, 491000\right.$ inhabitants). In the text below, we use TME to refer to both metalloids and metals. First, we measured the changes in blood and feather TME concentrations, molecular damages linked to ROS, the production of antioxidants such as GSH, and telomere length. Second, we evaluated the effect of Ca on these measures (pattern of accumulation, harmful effects on physiology) to evaluate the importance of its availability. Hence, half of the birds were supplemented with $\mathrm{Ca}$. An increase of TME concentrations in the blood and feathers of the TMEexposed group was expected, in association with an increase of ROM, which are representative of oxidative damages on lipids and proteins, telomere shortening and a modification in antioxidants levels (increase or decrease). An antagonistic effect of Ca on TME concentration and less harmful impacts in Ca-supplemented birds were also predicted.

\section{Material and methods}

\subsection{Animals and experimental design}

Experimentation was performed from February to April during the non-breeding period. Forty adult male zebra finches in their first year were randomly distributed in four groups of 10 individuals in cages of $150 \times 70 \times 100$ $\mathrm{cm}^{3}$ in a room with artificial lighting on a $14 \mathrm{~h}$ light $-10 \mathrm{~h}$ night cycle. To ensure homogeneity between cages, absence of significant differences in body mass and individual size (represented by tarsus size) between groups was verified at the beginning of the experiment (ANOVA test, $\mathrm{p}>0.05$ ). Each group had ad libitum access to seed mix (tropical finches Prestige Versele laga $\odot$ ) which contains low levels of $\mathrm{Ca}(1 \mathrm{mg} / \mathrm{g})$. After a two weeks habituation period, each group received a specific treatment provided in bottles of weakly mineralised drinking water (Montcalm(C). Administration of the treatment via drinking water permits to control birds' consumption and to know with accuracy the amount of TME consumed. Indeed, zebra finch is granivorous. Administration of the treatment by diet borne would have required to spike the seeds with a solution of the TME cocktail. The TME would have been located on the surface of seeds. However, birds usually remove the outer layer of the seed before eating them. In these conditions, control of the exposure to a precise quantity of TME would not have been possible. 
Treatment lasted for 57 days, with fresh preparations supplied every two days. We measured the quantity of water drunk for each cage after each replacement of cocktail bottles (no difference between groups, $p>0.05$ ). The duration of treatment was based on previous laboratory studies, which show significant physiological effects for similar exposure (Chatelain et al., 2016a; Dauwe et al., 2006; Scheuhammer, 1991). Two groups received a TME cocktail associated with either low or high $\mathrm{Ca}$ diet. The two other groups received only low or high Ca diet, without the TME cocktail. There is a lack of data on the effects of urban TME cocktail in birds in a controlled laboratory situation. Thus, to prepare a cocktail representative of urban exposure, the composition and concentrations of the TME cocktail were determined on the basis of fecal TME concentrations measurement of great tits captured in the Eurometropolis of Strasbourg, France (see Table A.1. of Supplementary materials for more details). Among the detected elements in great tits' feces, TME chosen for the cocktail were the TME whose concentrations are regulated by European legislation and/or which are known to have deleterious effects on birds. Fecal TME concentrations are correlated with food TME concentrations (Bel'skii et al., 1995; Dauwe et al., 2004) and represent both the non-assimilated portion of TME in food and the portion that has been assimilated and excreted. Thus, it represents the minimal exposure of birds. Moreover, these measures of fecal TME concentrations allow to assess the proportion of each TME in a cocktail. These concentrations are representative of the minimal chronic exposure in a medium-size city. Only $\mathrm{Pb}$ concentration was increased in the cocktail (1ppm measured but 10ppm in the cocktail) to work on values closer than those used in previously published experiments (Chatelain et al., 2016b; Dauwe et al., 2006; Snoeijs et al., 2005). Finally, the TME cocktail contained 10 ppm (48.3 $\mu \mathrm{M})$ of Pb (pure metal concentration prepared from $\left.\mathrm{PbCl}_{2}\right), 0.7 \mathrm{ppm}(13.5 \mu \mathrm{M})$ of $\mathrm{Cr}\left(\operatorname{as~} \mathrm{Cr}\left(\mathrm{NO}_{3}\right)_{3}\right), 1 \mathrm{ppm}(13.3 \mu \mathrm{M})$ of As (as $\left.\mathrm{NaAsO}_{2}\right), 100 \mathrm{ppm}\left(1.5 \mathrm{mM}\right.$ ) of $\mathrm{Zn}\left(\right.$ as $\left.\mathrm{ZnCl}_{2}\right), 24 \mathrm{ppm}(0.4 \mathrm{mM})$ of $\mathrm{Cu}\left(\right.$ as $\left.\mathrm{CuCl}_{2}\right), 0.5 \mathrm{ppm}(8.5 \mu \mathrm{M})$ of $\mathrm{Ni}$ $\left(\mathrm{NiCl}_{2}\right), 0.2 \mathrm{ppm}(3.4 \mu \mathrm{M})$ of $\mathrm{Co}\left(\right.$ as $\left.\mathrm{CoCl}_{2}\right)$ and $0.1 \mathrm{ppm}(0.9 \mu \mathrm{M})$ of $\mathrm{Cd}\left(\mathrm{CdCl}_{2}\right)$. Groups with high $\mathrm{Ca}$ diet received $1 \% \mathrm{Ca}$ in food (seed + water as $\mathrm{CaCl}_{2}$ ) associated with ad libitum cuttlefish bones. Low $\mathrm{Ca}$ diet groups received $0.3 \% \mathrm{Ca}$ in food, in accordance with the minimum recommended intake for this species and to avoid deprivation effects (Tully et al., 2000). Ca supplementation on water is regularly used in both wild (Poulin and Brigham, 2001) and laboratory (Damron and Flunker, 1995) studies. In brief, we had four groups: (1) 'TME' group: TME cocktail + $\mathrm{Ca} 0.3 \%$, (2)'TME + Ca' group: TME cocktail + $\mathrm{Ca} 1 \%$, (3) 'Ca' group: $\mathrm{Ca} 1 \%$, (4) 'Ctrl' group: $\mathrm{Ca} 0.3 \%$. Three birds died on the first 30 days of treatment ( 1 individual in ' $\mathrm{TME}+\mathrm{Ca}$ ' group, 1 in ' $\mathrm{Ca}$ ' group and 1 in 'Ctrl' group) and were not included in analyses. To avoid an effect of cage position, we switched top cages with bottom cages after 29 days of experimentation. This experiment has been approved by the French national ethical committee ${ }^{\circ} 35$ (project APAFIS\#12020-2017101116394831 v5).

2.2 Sampling

Before the treatment, tarsus length was measured with a calliper $( \pm 0.1 \mathrm{~mm})$ and body mass $( \pm 0.1 \mathrm{~g})$ with a precision scale. Blood and feathers were collected to measure physiological parameters and concentrations of TME in different tissues. During the experiment, birds and collected blood samples were weighed every two weeks. For blood samples, $100 \mu \mathrm{L}$ was taken from the brachial vein using $100 \mu \mathrm{L}$ heparinised capillaries and separated into two tubes of $50 \mu \mathrm{L}$. One tube was immediately frozen at $-20{ }^{\circ} \mathrm{C}$ for TME concentration analyses. The other one was centrifuged at $1700 \mathrm{RCF}$ for $10 \mathrm{~min}$ to separate plasma and erythrocytes before being conserved at $-20{ }^{\circ} \mathrm{C}$ for two months. Laboratory analyses were performed immediately after the end of the experimentation. On each bird, 
the right fourth primary feather was collected at 0 and 29 days of treatment. In this species, feathers are typically fully regrown in 26 days (Zann, 1996). Removed feathers were immediately frozen at $-20{ }^{\circ} \mathrm{C}$ for further TME concentration analyses.

\subsection{TME analyses in feather and blood}

TME concentrations were monitored in feathers and blood of birds. These two compartments were selected to realise non-invasive and longitudinal sampling. Moreover, the concentrations of TME in feather and blood are good indicators of metal exposure (Lodenius and Solonen, 2013).

Blood samples were weighted for digestion to assure a lower uncertainty on the TME concentration measurements than with volume sampling. Nitric acid solution $\left(\mathrm{HNO}_{3} 68 \%\right.$, trace quality) was added and the mixture was heated to $60^{\circ} \mathrm{C}$ for two hours. Then, digested samples were diluted with deionized water before analyses. The added quantity of nitric acid and deionized water was calculated for each sample following this proportion: $0.025 \mathrm{~g}$ of blood $+0.25 \mathrm{~mL}$ of $\mathrm{HNO}_{3}+$ deionized water QSP $2.5 \mathrm{~g}$. Using the same proportions of acid and water for all samples whatever the sample weight leads to better control of matrix effects during the measurements.

Total feathers ( 3 to $6 \mathrm{mg}$ depending on samples) were dehydrated overnight at $80^{\circ} \mathrm{C}$. Dried feathers were weighted and washed in $0.25 \mathrm{M} \mathrm{NaOH}$ and three ultrapure water baths according to the protocol described in Frantz et al. (2012). Then, feathers were fully covered with $1 \mathrm{~mL}$ of pure $\mathrm{HNO}_{3}$ solution $(68 \%$, TraceMetal grade, Fischer Chemicals) and digested overnight at $40{ }^{\circ} \mathrm{C}$ before dilution with ultrapure water to a final volume of $5 \mathrm{~mL}$. The concentration of each TME of the cocktail was determined by inductively coupled plasma mass spectrometry (ICPMS Agilent 7700 ) and was expressed in $\mu \mathrm{g} / \mathrm{kg}$ of blood samples or in $\mu \mathrm{g} / \mathrm{kg}$ dry mass for feather samples. TME concentration was determined using a calibration curve prepared by dilutions of a multi-element certified standard (10 $\mu \mathrm{g} / \mathrm{mL}$, CPI International). Indium $10 \mathrm{ppb}(1000 \mu \mathrm{g} / \mathrm{mL}$, CPI International) was used as an internal standard (See Table A.2 for the operational conditions of ICP-MS analysis). Analyses were performed on day 0, day 14, day 29, day 43 and day 57 for blood samples and on day 0 and day 29 for feather samples.

For both method, blanks were prepared and measured in the same way as blood and feather samples. Numerous values were under the limit of detection (LOD) of the instrument for blood analyses (See Table A.2 of Supplementary Material for the LOD of the ICP-MS analysis). For each TME, the instrumental LOD was calculated as the mean +3 standard deviation of 9 blank sample measurements. The method LOD reported in Tables A.2.1 and A.2.1 could change between the samples as the method LOD is impacted by the dilution factor, which depends on the sample mass available for analysis. Indeed, blood mass depends on the blood collected and is different according to individuals. Specificity of the analytical methods was checked by recovery measurements of spiked samples. Recovery values were $90-110 \%$ for all elements.

\subsection{Physiological analyses in erythrocytes and plasma}

Relative telomere length (RTL) was measured on erythrocytes (day 0, day 29 and day 57), by quantitative realtime amplification method (qPCR) adapted for birds, following the method of Criscuolo et al. (2009). DNA was 
extracted and purified with Nucleospin® Blood QuickPure kits (from Macherey-Nagel@). Then, the quantity and purity of the extracted DNA were measured using a microvolume spectrometer, the Nanodrop 1000 (Thermo scientific(C). The control used was glyceraldehyde-3-phosphate dehydrogenase (GAPDH) gene, specific of the zebra finch. Primers used for this control was GAPDH-F: 5'-AACCAGCCAAGTACGATGACAT-3' and GAPHD-R: 5'-CCATCAGCAGCAGCCTTCA-3' diluted to $5 \mathrm{nM}$. Primers used for telomere were Tel1b: 5'CGGTTTGTTTGGGTTTGGGTTTGGGTTTGGGTTTGGGTT-3' and Tel2b 5'GGCTTGCCTTACCCTTACCCTTACCCTACCCTTACCCT-3' diluted to $5 \mathrm{nM}$. Amplification cycle was performed with $5 \mathrm{ng}$ of DNA per well, and we used the GoTaq ${ }^{\circledR} \mathrm{qPCR}$ mix (Promega, Madison, USA). Conditions for telomere amplification started with $2 \mathrm{~min}$ at $95^{\circ} \mathrm{C}$ followed by 30 cycles of $30 \mathrm{sec}$ at $56^{\circ} \mathrm{C}, 30 \mathrm{sec}$ at $72^{\circ} \mathrm{C}$ and $1 \mathrm{~min} 15 \mathrm{sec}$ at $95^{\circ} \mathrm{C}$. For GAPDH, amplification started with $2 \mathrm{~min}$ at $95^{\circ} \mathrm{C}$ followed by 40 cycles of $1 \mathrm{~min}$ at 60 ${ }^{\circ} \mathrm{C}$ and $1 \mathrm{~min}$ at $95^{\circ} \mathrm{C}$. Each plate includes a serial dilution of referent individual's DNA ( $20 \mathrm{ng}, 10 \mathrm{ng}, 5 \mathrm{ng}, 2.5$ ng and $1.25 \mathrm{ng}$ ). These are used as a standard curve to control the amplification efficiency, which was $102.6 \%$ for GAPDH and $98.0 \%$ for telomere. Both negative control (water) and melting curves were run for each plate to check for non-specific amplification and primer-dimer artefacts. Each sample was run in duplicate. The RTL corresponds to the ratio (T/S) of telomere repeat copy number (T) to control gene copy number (S). The sample corresponding to the referent individual was designated 'golden sample' with a ratio (T/S) arbitrarily set to 1 . Mean intra-individual $\mathrm{Cq}$ (number of cycles necessary to detect amplified DNA above basal signal) variation was $0.57 \pm 0.04 \%$ for GAPDH assay and $1.62 \pm 0.12 \%$ for telomere assay. Mean inter-run Cq variation was $0.48 \pm$ $0.05 \%$ and $1.95 \pm 0.27 \%$ for GAPDH and telomere respectively.

\subsection{Oxidative stress measurement}

To evaluate oxidative damage, we measured ROM such as hydroperoxides concentration in bird's plasma (day 0 , day 29, day 57). Hydroperoxides are a result of oxidation of several molecules like lipid or glucoside by ROS. Measures were performed using the d-ROM test (diacron- reactive oxygen metabolite test, Diacron, Italy), adapted in 96 wells plate. Briefly, $200 \mu \mathrm{L}$ of the provided acid buffer combined to a chromogenic substrate was added to $4 \mu \mathrm{L}$ of plasma to cause iron salting-out and incubated at $37^{\circ} \mathrm{C}$ during $75 \mathrm{~min}$. With iron, hydroperoxide was converted in alkoxyl and peroxyl radicals by Fenton reaction. Free radicals will then react with the chromogenic substrate that turns pink when oxidised. The absorbance of the samples is then measured at $510 \mathrm{~nm}$. The value obtained is directly proportional to the ROM in the sample. Concentration was determined with a standard sample with known absorbance and converted to $\mathrm{mg}$ of $\mathrm{H} 2 \mathrm{O} 2 / \mathrm{dL}$ (based on Carrateli Units) following the kit instructions. Samples were run in duplicates. Mean coefficient of intra-individual and inter-plate variation was $4.99 \% \pm 1.96$ and $6.25 \%$ respectively.

Associated with oxidative damage, we performed some antioxidant measures. We measured total (GSHtot), free (GSH) and oxidised glutathione (GSSG) concentration and glutathione peroxidase activity (GPx) on erythrocytes. Glutathione concentration (GSHtot, GSH and GSSG), in $\mu \mathrm{mol} / \mathrm{L}$, was determined using a $5 \times 96$ well Glutathione Fluorescence kit (Arbor Assay, USA) on 1:100 diluted erythrocytes in $5 \%$ of 5-sulfosalicylic acids (SSA) (as recommended by the fabricant instructions. GPx, in U/mg erythrocytes, was measured with a Randox kit (Ransel, UK) adapted in 96 wells plate, in $5 \mu \mathrm{L}$ of 1:40 diluted erythrocytes using the diluting buffer provided with the kit. Samples were run in duplicates. of intra-individual variations were of $1.75 \% \pm 0.75 \%, 3.78 \% \pm 2.33 \%, 2.25 \% \pm$ 
$1.67 \%$ for GSHtot, GSH and GPx respectively. Mean coefficients of inter-plate variation was of $2.70 \%$ and $4.30 \%$ for GSHtot and GPx respectively.

\subsection{Statistical analyses}

Statistical analyses were conducted with R software (3.4.3 version) with 'nlme', 'car', 'lme4' and 'multicomp' packages (R Development Core Team, 2016).

\subsubsection{Effect of TME and Ca supplementation on TME concentrations in blood and feathers}

Statistical approaches were different between blood and feather concentrations. For feathers, all TME concentrations were above the LOD except Co concentrations. We performed statistical tests taking into account the "cocktail" effect of metals on physiology and allowing the visualisation of accumulation patterns. On the contrary, in blood, there were many metal concentrations under the LOD, except for $\mathrm{Cu}$ and $\mathrm{Zn}$. Thus, calculations have been done for each TME considered individually. Data under the LOD indicate that these concentrations are very low and cannot be determined. But this data is different from a missing value. This kind of dataset, with both exact values (above the LOD) and non-exact values (below the LOD), is a left-censored dataset and can be analysed with specific statistical tools such as those developed in the NADA package (Helsel, 2011). More precisely, for blood, we used a non-parametric score test that determines whether distribution function differs among groups of censored data. This is called a generalized Wilcoxon test or a Peto-Prentice test (cendiff function in the NADA package). The advantage of score tests is that they can handle data censored at multiple reporting limits (Helsel, 2011).

Differences between treatments were tested at each exposure time. When Wilcoxon scores were significant, multiple comparison tests were performed between each pair of groups with a Bonferroni correction of the p-value: $\mathrm{p}$-value pairwise $=0.05 /$ number of comparison. Corrected $\mathrm{p}$-value was equal to 0.0083 ( 6 pairs of comparisons) for multiple treatment comparisons. We considered as significant only the tests with a p-value less than or equal to this value.

For TME concentrations in feathers, principal component analyses (PCA) were performed to observe the relationships between metals and differences in accumulation patterns between groups. Co was excluded from the PCA because numerous values were under the LOD. Before analyses, feather TME concentrations were scaled and centred to normalize the distribution. The Bartlett's test for sphericity $\left(\chi^{2} \operatorname{ddl}(28)=190.5, p\right.$-value $\left.<0.01\right)$ and correlations were ran to ensure data appropriateness for PCA $(p<0,05)$. For each individual, the composite variables PC1Feather and PC2Feather corresponding to the first and second principal components of the PCA, respectively, were extracted. To test the differences of PCA components (PCA1Feather and PCA2Feather) between treatments, mixed effect linear models were performed followed by ANOVA of type III for each component. Models included treatment, exposure time and their interaction as explanatory variables and individual as a random effect (Bird ID) to take into account the non-independence of repeated measures on the same individual. When ANOVA were significant, Tukey multiple comparison tests ('multicomp' package) were used to perform post-hoc tests. Normality and homoscedasticity of residuals were verified with Kolmogorov-Smirnov and Bartlett test, respectively. These variables (PCA1Feather and PCA2Feather) were also used as explanatory variables in models for physiological analyses. 
Before treatment, the homogeneity in body mass and tarsus length (representative of body size) between groups were checked with ANOVA type III test. There were no differences between groups (body mass: $\mathrm{F}_{3,34}=1.12$, pvalue $=0.36, \log ($ tarsus $): F_{3,33}=0.87, \mathrm{p}$-value $\left.=0.47\right)$.

Influence of the treatment on physiological parameters and body mass were analysed using mixed effects linear models followed by type III ANOVA. We tested seven models: body mass, telomere length, GSH, GSSG, GSHtot concentration, GPx activity and ROM concentration. The best model for each parameter was selected using a stepwise method based on the p-value. For each model tested, the variable or interaction with higher p-value was deleted until only significant variables were left $(\mathrm{p}<0.05)$. When none of the variables was significant, the last non-significant variable was kept. In all models, the random effect was the individual (bird ID) to take into account the non-independence of repeated measures on the same individual. Concerning fixed effects, full models included treatment, time of treatment and its interaction as explanatory variables with body mass and tarsus length as covariates. For body mass model, only tarsus length was a covariate. When variables were significant, Tukey multiple comparison tests ('multicomp' package) were used to perform post-hoc tests. Direct effect of TME exposure on physiological parameters was also tested. For each physiological parameter, linear mixed models were run with variables PC1Feather and PC2Feather as an explanatory variable (with bird ID as a random effect). For blood, we performed linear mixed models between each physiological parameter and single TME concentration above the LOD (with bird ID as random effect). For all linear models, normality and homoscedasticity of residuals were checked with Kolmogorov-Smirnov and Bartlett test respectively. To validate these conditions, telomere length, GSH (free, total and GSSG), ROM and GPx were log-transformed. For free GSH and body mass, we applied treatment-dependent variance (option varIdent) in our models (Zuur et al., 2009) because homoscedasticity was not respected.

\section{Results and discussion}

In blood, statistical analyses on Co could not be performed because Co concentrations above LOD represent only $13.9 \%$ of all values (Table 1). When values above LOD represent less than $20 \%$ of dataset, statistical tests are unreliable (Helsel, 2011). In blood, less than $50 \%$ of values were above the detection limits for $\mathrm{Cr}, \mathrm{Cd}, \mathrm{Ni}$ and $\mathrm{As}$ (22.8\% for $\mathrm{Cr}, 26.1 \%$ for $\mathrm{Cd}, 35.3 \%$ for $\mathrm{Ni}$ and $37.7 \%$ for $\mathrm{As}$ ). $\mathrm{Pb}$ concentrations above LOD represented $66.1 \%$ of total values, and $\mathrm{Zn}$ and $\mathrm{Cu}$ concentrations were all above the detection limits. In feathers, all values were above the LOD except for Co (75\%). Nevertheless, we did not include the Co in the statistical analysis because we did a PCA analysis that cannot handle censored values (see material and methods).

3.1 Effect of the exposition to TME cocktail and Ca supplementation on blood and feather TME concentrations

Concerning the concentration of TME in blood, generalised Wilcoxon tests show no significant difference between treatments at day 0 , except for As (Table 2). Nevertheless, pairwise comparisons revealed no significant differences for this TME (Table 1, p-values $>0.0083$, See Table A.3 of Supplementary material for values of pairwise tests and p-values). Several significant effects of groups (for example at day 14 for $\mathrm{Cr}$ or $\mathrm{Cd}$ ) were not 
higher for the period from day 14 to day 57 compared to day 0 . The 'TME' group presented higher concentrations than the three other groups at day 14, 29, 43 and 57 (Table 2, p-values >0.0083) for Pb (except for day 14) and As. Rich-calcium diet seemed to limit the increase of these two TME concentration in the blood of 'TME $+\mathrm{Ca}$ ' birds. At the end of the experiment (day 57), As concentration was higher in the 'TME' group compared to the other groups and the $\mathrm{Pb}$ concentration was higher in the 'TME' group and ' $\mathrm{Ca}$ ' group (only one value) than in other groups. Otherwise, Zn concentration was higher in both TME-supplemented groups ('TME' and 'TME+Ca') at day 29 and only in 'Ca' group compared to "ctrl” group at day 43.

The PCA for TME in feathers explained $54.81 \%$ of the total variation of TME concentration in feathers (Fig. 1). The first principal component PC1Feather (36.94\% of the variation) was mostly explained and positively correlated with $\mathrm{Cu}$ and also with $\mathrm{Zn}, \mathrm{Cr}$ and $\mathrm{Pb}$ concentrations, but all TME were significantly associated with this component $(\mathrm{p}<0.05)$ (see Table A.4 of supplementary material for contributions and p-values). The second principal component $\mathrm{PC} 2 \mathrm{Feather}$ (18.17\% of the variation) was positively correlated with $\mathrm{Cd}, \mathrm{Pb}$ and $\mathrm{As}$ and negatively with $\mathrm{Ni}, \mathrm{Zn}$ and $\mathrm{Cr}$. At day 0 , the four groups were superposed and presented low concentrations of TME along both axes. PC1Feather separates feather TME concentrations of 'TME' and 'TME+Ca' groups at day 29 from the initial time and the other groups (see Table A.5 of Supplementary material for TME concentrations in feathers). This pattern indicates that birds in TME-exposed groups ('TME' and 'TME+Ca') presented higher concentrations of TME in their regrown feathers (day 29) than in the initial feather and in all feathers of non-TME exposed birds, especially for $\mathrm{Cu}, \mathrm{Zn}, \mathrm{Cr}$ and $\mathrm{Pb}$. These differences are significant (Table 3; Tuckey test, $\mathrm{p}$ values $<0.05$, see Table A.4 of supplementary material for all Tukey p-values), except between groups 'TME' at

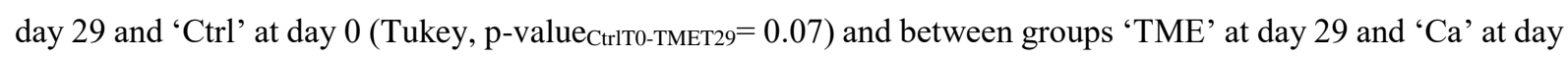
29 (Tuckey test, p-value ${ }_{\text {CaT0-TMET29 }}=0.37$ ). Interestingly, PC2Feathers separates Ca supplemented groups ('Ca' and ' $\mathrm{TME}+\mathrm{Ca}$ ') and 'TME' group in regrown feathers (day 29), and their TME concentrations were significantly different (Table 3, Tukey test, p-value TMET29-CaT29 and p-value $_{\text {TMET29-TME+CaT29 }}<0.001$, p-value CaT29-TME+CaT29 $_{\text {TM.95). }}$. Ca supplemented groups (' $\mathrm{Ca}$ ' and ' $\mathrm{TME}+\mathrm{Ca}$ ') accumulated a higher concentration of $\mathrm{Zn}, \mathrm{Ni}$ and $\mathrm{Cr}$ than 'TME' group, which accumulated a higher concentration of $\mathrm{Cd}, \mathrm{Pb}$ and $\mathrm{As}$.

These results confirm that chronic exposure to a low concentration TME cocktail leads to the increase of TME in blood and feathers notably in the non-essential TME Cd (feathers), Pb (blood and feathers) and As (blood and feathers). Interestingly, these results also suggest that $\mathrm{Ca}$ supplementation leads to an increase of $\mathrm{Zn}, \mathrm{Cr}$, and $\mathrm{Ni}$ concentrations in the feathers of TME exposed birds but also for $\mathrm{Zn}$ in TME-unexposed birds. On the contrary, the fact that we found less $\mathrm{As}$ and $\mathrm{Pb}$ in blood and less $\mathrm{As}, \mathrm{Pb}$ and $\mathrm{Cd}$ in the feathers of $\mathrm{Ca}$-rich diet birds confirmed our initial hypothesis about the antagonistic effects of Ca supplementation on non-essentials TME. Indeed, the interaction between $\mathrm{Pb}$ and $\mathrm{Ca}$ is already well documented. For example in mammals, Six and Goyer (1970) found similar results in $\mathrm{Pb}$-exposed rat: blood levels of $\mathrm{Pb}$ is lower for animals with normal $\mathrm{Ca}$ diet $(0.7 \%)$ compared to those with low-Ca diet $(0.1 \%)$. The antagonistic effect was demonstrated in organs like the kidney, bones and liver (Dauwe et al., 2006; Snoeijs et al., 2005). In zebra finches exposed to $20 \mathrm{ppm}$ of $\mathrm{Pb}, \mathrm{Pb}$ accumulation in organs (bones, livers, kidney, muscle and brain) is 2.2 to 3.1 times lower in oyster shell grit supplemented birds (Dauwe et al. 2006). The same mechanism was observed for $\mathrm{Cd}$, in which low $\mathrm{Ca}$ availability leads to higher accumulation of this metal in tissues, especially in bones (Jaishankar et al., 2014; Scheuhammer, 1996; Stohs and Bagchi, 1995). However, the relation between a calcium-rich diet and As accumulation is less documented and seems to be 
dependent on the tissue. For example, in pollution-exposed birds, As was found in eggshell, mainly composed of Ca, but not in the content of the eggs (Dauwe et al., 2005, 1999; Mora, 2003). Similarly, As supplementation leads to an accumulation of this element in the bones (composed largely of $\mathrm{Ca}$ ) of great tits (Sánchez-Virosta et al., 2018), but supplementation of Ca did not reduce the concentration of As in the blood and kidneys of As-exposed rats (Srivastava et al., 2010). The mechanism of interaction between As and Ca could be potentially explained by complexation mechanisms of $\mathrm{Ca}$ on $\mathrm{As}$ (Arsenic V form) leading to neutral and non-bioavailable species $\mathrm{CaHAsO}_{4}$ and $\mathrm{Ca}_{3}\left(\mathrm{AsO}_{4}\right)_{2}$ (Wang et al., 2008). However, the increase of essential-TME in the feathers of Ca supplemented groups was unexpected but severals hypotheses can be suggested. The accumulation of $\mathrm{Zn}, \mathrm{Ni}$ and $\mathrm{Cr}$ is favoured by Ca pathway. Some studies have shown that the divalent cation form of $\mathrm{Ni}$ and $\mathrm{Zn}$ metals can compete with $\mathrm{Ca}$ for binding sites on Ca channels or calcium-binding proteins, for example (Komjarova and Blust, 2009). Zn also contributes to the keratinization process explaining its high concentrations in feathers (Ek et al., 2004). In the same way, the accumulation of $\mathrm{Cr}$ in Ca-exposed bird is potentially linked to $\mathrm{Zn}$ homeostasis as revealed in zincdeficient rats supplemented with $\mathrm{Cr}$ (Hahn and Evans, 2017).

\subsection{Effect of the exposition to TME cocktail and Ca supplementation on body mass and physiological} parameters

There was no significant effect of TME exposure or Ca supplementation on the body mass or telomere length of birds (p-value > 0.05, statistics in Table 4, see Table A.6 of supplementary material for estimates values). Concerning the oxidative status, exposure time had a significant effect on ROM, GSSG and GSHtot concentrations (Tables 4 and 5). ROM concentration of birds was lower at 57 days of treatment compared to the two previous periods T0 and T29 (Tukey: $\mathrm{p}_{\mathrm{T} 57-\mathrm{T} 0}=0.002, \mathrm{p}_{\mathrm{T} 57-\mathrm{T} 29}=0.0003$, and $\mathrm{p}_{\mathrm{T} 0-\mathrm{T} 29}=0.84$ ). On the contrary, GSSG and GSHtot values were higher after 57 days of treatment compared to values measured after 0 and 29 days of treatment (Tukey

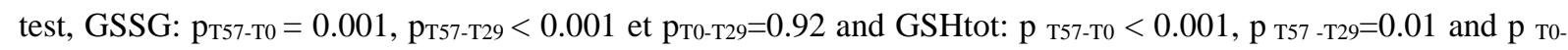
${ }_{\mathrm{T} 29}=0.58$ ). For GSH and GPx activity, the interaction between treatment and exposure time was significant. However, pairwise comparison only revealed that GSH concentration of 'TME' group at 57 days was higher than the concentration in the 'Ca' group at day 0 (Tukey test, peTM57-CaT0 $=0.04$ ). Similarly, GPx activity in 'Ca' group

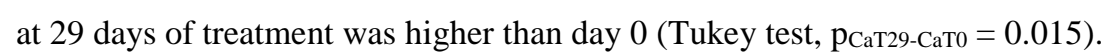

There was also no significant correlation between physiological parameters and concentration of single TME in blood (Table 6). However, linear models with composite variables PC1Feather and PC2Feathers revealed a significant negative effect of PC2Feather on telomere length $\left(F_{1,35}=4.23\right.$, p-value $\left.=0.047\right)$ but no significant effects of PC1Feathers $\left(F_{1,35}=1.08\right.$, p-value=0.31). Telomere length was shorter in individuals with high concentrations of $\mathrm{Pb}, \mathrm{Cd}$ and $\mathrm{As}$ and lower concentrations of $\mathrm{Zn}, \mathrm{Cr}$ and $\mathrm{Ni}$ in feathers (Fig. A.1 of supplementary material). There was no significant effect of composite variables of PCA on the other physiological parameters (Table 4).

The fact that birds with higher accumulated concentrations of $\mathrm{Pb}$, As and $\mathrm{Cd}$ in feather had shorter telomeres, is concordant with the work of Stauffer et al. (2017). They found shorter telomeres in great tits nestling living in a metal-polluted area compared to a non-polluted area. Nevertheless, contrary to their study, our results suggest a direct correlation between TME concentration in tissue and telomere length. Several studies have shown the genotoxicity of $\mathrm{Pb}$, As and Cd exposure (Koivula and Eeva, 2010). Genotoxicity of these TME is for a major part linked to an increase of ROS production, which can interact with oxidised DNA bases and leads to strand breaks, 
but, it is also linked to the inhibition of DNA reparation mechanisms (Stohs and Bagchi, 1995). For example, Japanese quails (Coturnix japonica) exposed to $100 \mathrm{ppm}$ of $\mathrm{Pb}$ exhibit higher plasmatic concentrations of 8hydroxy-2-deoxyguanosine (oxidised by-product of guanine) indicating more DNA strand breaks compared to unexposed birds (Farag et al., 2018). In the same way, after 40 days of exposure to 1 and 10 ppm Cd, Lucia et al. (2009) observed expression of the DNA damage repairing gene, ggsh, of 6.5 and 19.5 times greater respectively in Muscovy duck (Cairina moschata). In Spain, the blood of white stork (Ciconia ciconia) nestlings present a similar concentration of As (i.e. $0.02 \mathrm{ppm}$ ) and lower concentrations of $\mathrm{Cd}$ (i.e. 0.00031) than our birds and they find a significant correlation between DNA damages and As and Cd concentration (Baos et al., 2006). Our results suggest that even low concentration exposure could lead to accelerated telomere attrition on birds living in metalpolluted areas, which could affect their longevity (Epel et al., 2004). However, telomere length of birds in 'TME' group was not different from length for birds exposed to other treatments or at the initial time. This absence of significant effect can be explained by the fact that birds which exhibited high concentrations of $\mathrm{As}, \mathrm{Pb}$, or $\mathrm{Cd}$ were not necessarily in the 'TME' group. For example, there was no significant difference between 'TME' at day 29 and 'Ctrl' at day 0 and 'TME' at day 29 and ' $\mathrm{Ca}$ ' at day 29 along the axis PC1Feather. In the first case, it is probably because birds of ' $\mathrm{Ctrl}$ ' group at day 0 exhibited similar levels of $\mathrm{Pb}$ and $\mathrm{Cd}$ in feathers as the 'TME' group at day 29. The concentrations of these TME in 'Ctrl' group decreased during the experiment and thus concentrations at day 29 in 'Ctrl' group were lower than concentration in initial feathers. In the second case, it could be linked to the fact that 'Ca' group exhibited higher Zn concentration at day 0 compared to day 29.

There was no significant relationship between feather and blood TME concentration and antioxidants measured (GSH, GSSG and GSHtot and GPx) nor between treatment and measured antioxidants. Results only showed a time-dependent increase of GSHtot and GSSG whatever the treatments. Several field-studies exhibit a significant correlation between TME concentration in tissues and antioxidant production (De la Casa-Resino et al., 2015; Espín et al., 2014a; Stauffer et al., 2017). For example, in wild griffon vulture (Gyps fulvus), a blood concentration higher than 0.15 ppm of Pb leads to an inhibition of GPx activity (Espín et al., 2014a). In the same way, the blood GSH concentration of white stork nestlings living in a TME-polluted area (in blood, $21 \mu \mathrm{g} / \mathrm{L}$ of As and 0.103 $\mu / \mathrm{L}$ of $\mathrm{Pb}$ respectively) is 3.9 times higher than birds living in non-polluted areas (De la Casa-Resino et al. 2015). In great tits females, high concentration of $\mathrm{As}$ and $\mathrm{Pb}$ in feces is correlated with GPx inhibition, but not with GSH and GSHtot (Stauffer et al. 2017) whereas in pied flycatcher females (Ficedula hypoleuca) As and Pb in feces is positively correlated with GSH and GSHtot concentration. (Berglund et al., 2007). However, other studies show no significant effect of TME-exposition on GPx or GSHtot (Berglund et al., 2007, 2014; Koivula et al., 2011). For example, pied flycatcher nestlings living in TME-polluted areas present higher catalase, glutathione reductase and glutathione-S-transferase activity than birds in non-polluted areas but no significant differences in GPx and GSHtot was observed between the two areas (Berglund et al., 2007). GSH and GPx activity are a strong marker of oxidative stress linked to TME exposure (Koivula and Eeva, 2010), but the antioxidant mechanism against TME exposure seems to be different between species (Berglund et al., 2011; Espín et al., 2016b; Rainio et al., 2013; Stauffer et al., 2017). It is possible that other biomarkers, such as superoxide dismutase activity or catalase activity, would have been more impacted by exposure to TME. The time-dependent increase of GSHtot and GPx in our study was associated with a time-dependent decrease of ROM. This result could be an answer to physiological stress due to frequent manipulation of birds during the experiment. The stress linked to the manipulation could lead to the increase of ROM, which in turn, have led to the production of GSHtot to neutralize them. 
There was no significant correlation between ROM and TME concentration in tissue. If telomere length attrition is linked to ROS production, ROS has no visible impacts on lipid and protein damages nor glutathione metabolism. Several studies have shown that TME exposure leads to an increase in oxidative damage including lipid peroxidation (Espín et al., 2014a; Kurhalyuk et al., 2009; Prasanthi et al., 2010; Stauffer et al., 2017) but it also seems to depend on the species. For example, lipid peroxidation is measured in blood (at concentrations higher than $0.15 \mathrm{ppm}$ of $\mathrm{Pb}$ ) in the griffon vulture (Espín et al., 2014a) but not in white storks (De la Casa-Resino et al., 2015). Moreover, some studies show that the correlative negative effects of TME-polluted environments on wild birds could be linked to other factors such as food availability or food quality (Eeva et al., 2005, 2003; Koivula et al., 2011). A decrease of carotenoid content in prey is detected in polluted sites (Koivula et al., 2011). Oxidative stress in great tit chicks is related to the prey quality but not to TME-concentration exposure. In the present study, the absence of a significant effect on glutathione metabolism may be the result of the use of dietary antioxidant such as carotenoids by birds. Animals were in a protected laboratory environment with ad libitum food of high quality (except for $\mathrm{Ca}$ in two groups of birds). They have no physiological and ecological constraint and can allocate more resources to overcome TME and their consequences.

Limited $\mathrm{As}$ and $\mathrm{Pb}$ concentrations in blood in Ca-supplemented birds could also explain the absence of effects caused by the TME cocktail on physiological parameters, especially on telomere length. Ca bioavailability indirectly protects against the toxicity of TME by preventing their accumulation. Moreover, a Ca supplementation can enhance the antioxidant capacity of birds, as has been shown experimentally in wild great tits (Sánchez-Virosta et al. 2019).The increase of these essential TME in feathers in the case of Ca supplementation could also explain the higher telomere length. The essentials TME could thus protect the organism against the harmful effects of nonessential TME. Previous studies have shown the beneficial effects of $\mathrm{Zn}$ supplementation on oxidative stress and accumulation of non-essential TME in the brain (Goyer, 1997; Kucuk, 2008; Prasanthi et al., 2010). In addition, mice exposed to $2000 \mathrm{ppm}$ of $\mathrm{Pb}$ showed less lipid peroxidation and radical formation with supplementation of 200 ppm of Zn (Prasanthi et al., 2010).

\section{Conclusion}

The aim of this study was to experimentally evaluate the effects of a TME cocktail, representative of urban exposure, on the concentration of these TME in the blood and feathers, and on the physiology of a passerine bird. The second aim was to test the role of the availability of $\mathrm{Ca}$ on the effects of this cocktail. There are numerous factors in urban areas, which can influence the physiology of birds. In the wild, it is difficult to tease apart the effect of each pollutant. Laboratory experiments are crucial to understand the impact of each category of pollutant, but it should be representative of natural phenomenon. Our results suggest that chronic exposure to a TME cocktail at low concentrations, representative of minimal exposure in a medium-size city, could have a deleterious effect on physiological parameters of birds. Exposure to TME seems to lead to an increase of telomere attrition and therefore could reduce the longevity of birds. Low effect of TME cocktail on the measured oxidative status biomarker suggests that TME concentrations are potentially too low to activate the glutathione metabolism pathway, or that birds can compensate with other antioxidants, such as dietary antioxidants. Ca bioavailability seems to be important to fight against the harmful effects of TME exposure, in limiting the accumulation of nonessential metals and metalloid promoting the accumulation of essential metals. Future studies should be conducted to decrypt the effects of TME on telomere length and longevity in urban birds, notably the effect of early-life 
exposure. In laboratory, TME cocktail exposure during reproduction or combined with food limitation could provide a more realistic simulation of natural conditions at certain moments in the life cycle. In addition, it seems to be essential to take into account Ca bioavailability when studying the consequences of exposure to TME.

\section{ACKNOWLEDGEMENTS}

We thank A. Hranitzky, M-L Rizzi and H. Gachot for their help with animal care and F. Criscuolo for his help during physiological parameters analyses. A. Saulnier was supported by a Ph.D grant from the French Ministry of Research.

\section{FUNDING}

This work was supported by funding of the project ECOMU (2017-2018) of the national interdisciplinary program EC2CO/ECODYN of Institut National des Sciences de l'Univers, Centre National de la Recherche Scientifique and the project 'Ecodynamic of heavy metals in environment' of the master project 'RN in the environment' of Institut National de Physique Nucléaire et de Physique des Particules (IN2P3 / CNRS).

\section{REFERENCES}

Baos, R., Jovani, R., Pastor, N., Tella, J.L., Jiménez, B., Gómez, G., González, M.J., Hiraldo, F., 2006. Evaluation of genotoxic effects of heavy metals and arsenic in wild nestling white storks (Ciconia ciconia) and black kites (Milvus migrans) from Southwestern Spain after a mining accident. Environ. Toxicol. Chem. 25, 27942803. https://doi.org/10.1897/05-570R.1

Bel'skii, E.A., Bezel, V.S., Lyakhov, A.G., 1995. Characteristics of the reproductive indices of birds nesting in tree hollows under conditions of technogenic pollution. Russ. J. Ecol. 26, 126-131.

Berglund, Å.M.M., Koivula, M.J., Eeva, T., 2011. Species- and age-related variation in metal exposure and accumulation of two passerine bird species. Environ. Pollut. 159, 2368-2374. https://doi.org/10.1016/j.envpol.2011.07.001

Berglund, Å.M.M., Sturve, J., Förlin, L., Nyholm, N.E.I., 2007. Oxidative stress in pied flycatcher (Ficedula hypoleuca) nestlings from metal contaminated environments in northern Sweden. Environ. Res. 105, 330339. https://doi.org/10.1016/j.envres.2007.06.002

Berglund, Å.M.M.M., Rainio, M.J., Kanerva, M., Nikinmaa, M., Eeva, T., 2014. Antioxidant status in relation to age, condition, reproductive performance and pollution in three passerine species. J. Avian Biol. 45, 235246. https://doi.org/10.1111/j.1600-048X.2013.00126.x

Boonekamp, J.J., Bauch, C., Mulder, E., Verhulst, S., 2017. Does oxidative stress shorten telomeres? Biol. Lett. 13, 20170164. https://doi.org/10.1098/rsbl.2017.0164

Chatelain, M., Gasparini, J., Frantz, A., 2016a. Do trace metals select for darker birds in urban areas? An experimental exposure to lead and zinc. Glob. Chang. Biol. 22, 2380-2391. https://doi.org/10.1111/gcb.13170 
Chatelain, M., Gasparini, J., Haussy, C., Frantz, A., 2016b. Trace metals affect early maternal transfer of immune components in the feral pigeon. Physiol. Biochem. Zool. 89, 206-212. https://doi.org/10.1086/685511

Criscuolo, F., Bize, P., Nasir, L., Metcalfe, N.B., Foote, C.G., Griffiths, K., Gault, E.A., Monaghan, P., 2009. Realtime quantitative PCR assay for measurement of avian telomeres. J. Avian Biol. 40, 342-347. https://doi.org/10.1111/j.1600-048X.2008.04623.x

Damron, B.L., Flunker, L.K., 1995. Calcium supplementation of hen drinking water. Poult. Sci. 74, $784-787$. https://doi.org/10.3382/ps.0740784

Dauwe, T., Bervoets, L., Blust, R., Pinxten, R., Eens, M., 1999. Are eggshells and egg contents of great and blue tits suitable as indicators of heavy metal pollution? Belgian J. Zool. 129, 439-447.

Dauwe, T., Janssens, E., Bervoets, L., Blust, R., Eens, M., 2005. Heavy-metal concentrations in female laying great tits (Parus major) and their clutches. Arch. Environ. Contam. Toxicol. 49, $249-256$. https://doi.org/10.1007/s00244-003-0209-z

Dauwe, T., Janssens, E., Bervoets, L., Blust, R., Eens, M., 2004. Relationships between metal concentrations in great tit nestlings and their environment and food. Environ. Pollut. 131, 373-380. https://doi.org/10.1016/j.envpol.2004.03.009

Dauwe, T., Snoeijs, T., Bervoets, L., Blust, R., Eens, M., 2006. Calcium availability influences lead accumulation in a passerine bird. Anim. Biol. 56, 289-298. https://doi.org/10.1163/157075606778441822

De la Casa-Resino, I., Hernández-Moreno, D., Castellano, A., Soler Rodríguez, F., Pérez-López, M., 2015. Biomarkers of oxidative status associated with metal pollution in the blood of the white stork (Ciconia ciconia) in Spain. Toxicol. Environ. Chem. 97, 588-598. https://doi.org/10.1080/02772248.2015.1051484

Duffus, J.H., 2002. "Heavy metals" - A meaningless term? (IUPAC technical report). Pure Appl. Chem. 74, 793807. https://doi.org/10.1351/pac200274050793

Eeva, T., Hasselquist, D., Langefors, Å., Tummeleht, L., Nikinmaa, M., Ilmonen, P., 2005. Pollution related effects on immune function and stress in a free-living population of pied flycatcher Ficedula hypoleuca. J. Avian Biol. 36, 405-412. https://doi.org/10.1111/j.0908-8857.2005.03449.x

Eeva, T., Lehikoinen, E., 2004. Rich calcium availability diminishes heavy metal toxicity in Pied Flycatcher. Funct. Ecol. 18, 548-553. https://doi.org/10.1111/j.0269-8463.2004.00875.x

Eeva, T., Lehikoinen, E., Nikinmaa, M., 2003. Pollution-induced nutritional stress in birds: An experimental study of direct and indirect effects. Ecol. Appl. 13, 1242-1249. https://doi.org/10.1890/01-5375

Ek, K.H., Morrison, G.M., Lindberg, P., Rauch, S., 2004. Comparative tissue distribution of metals in birds in Sweden using ICP-MS and laser ablation ICP-MS. Arch. Environ. Contam. Toxicol. 47, $259-269$. https://doi.org/10.1007/s00244-004-3138-6

Epel, E.S., Blackburn, E.H., Lin, J., Dhabhar, F.S., Adler, N.E., Morrow, J.D., Cawthon, R.M., 2004. Accelerated telomere shortening in response to life stress. Proc. Natl. Acad. Sci. 101, 17312-17315. 
Espín, S., García-Fernández, A.J., Herzke, D., Shore, R.F., van Hattum, B., Martínez-López, E., Coeurdassier, M., Eulaers, I., Fritsch, C., Gómez-Ramírez, P., Jaspers, V.L.B., Krone, O., Duke, G., Helander, B., Mateo, R., Movalli, P., Sonne, C., van den Brink, N.W., 2016a. Tracking pan-continental trends in environmental contamination using sentinel raptors_-what types of samples should we use? Ecotoxicology 25, 777-801. https://doi.org/10.1007/s10646-016-1636-8

Espín, S., Martínez-López, E., Jiménez, P., María-Mojica, P., García-Fernández, A.J., 2016b. Interspecific differences in the antioxidant capacity of two Laridae species exposed to metals. Environ. Res. 147, 115124. https://doi.org/10.1016/j.envres.2016.01.029

Espín, S., Martínez-López, E., Jiménez, P., María-Mojica, P., García-Fernández, A.J., 2014a. Effects of heavy metals on biomarkers for oxidative stress in Griffon vulture (Gyps fulvus). Environ. Res. 129, 59-68. https://doi.org/10.1016/j.envres.2013.11.008

Espín, S., Martínez-López, E., León-Ortega, M., Martínez, J.E., García-Fernández, A.J., 2014b. Oxidative stress biomarkers in Eurasian eagle owls (Bubo bubo) in three different scenarios of heavy metal exposure. Environ. Res. 131, 134-144. https://doi.org/10.1016/j.envres.2014.03.015

Espín, S., Ruiz, S., Sánchez-Virosta, P., Eeva, T., 2016c. Effects of calcium supplementation on growth and biochemistry in two passerine species breeding in a Ca-poor and metal-polluted area. Environ. Sci. Pollut. Res. 23, 9809-9821. https://doi.org/10.1007/s11356-016-6219-y

Espín, S., Ruiz, S., Sánchez-Virosta, P., Lilley, T., Eeva, T., 2017. Oxidative status in relation to metal pollution and calcium availability in pied flycatcher nestlings - A calcium manipulation experiment. Environ. Pollut. 229, 448-458. https://doi.org/10.1016/j.envpol.2017.05.094

Farag, M.R., Alagawany, M., Abd El-Hack, M.E., El-Sayed, S.A.A., Ahmed, S.Y.A., Samak, D.H., 2018. Yucca schidigera extract modulates the lead-induced oxidative damage, nephropathy and altered inflammatory response and glucose homeostasis in Japanese quails. Ecotoxicol. Environ. Saf. 156, 311-321. https://doi.org/10.1016/j.ecoenv.2018.03.010

Fraga, C.G., 2005. Relevance, essentiality and toxicity of trace elements in human health. Mol. Aspects Med. https://doi.org/10.1016/j.mam.2005.07.013

Frantz, A., Pottier, M.A., Karimi, B., Corbel, H., Aubry, E., Haussy, C., Gasparini, J., Castrec-Rouelle, M., 2012. Contrasting levels of heavy metals in the feathers of urban pigeons from close habitats suggest limited movements at a restricted scale. Environ. Pollut. 168, 23-28. https://doi.org/10.1016/j.envpol.2012.04.003

Goyer, R.A., 1997. Toxic and essential metal interactions. Annu. Rev. Nutr. 17, 37-50. https://doi.org/10.1146/annurev.nutr.17.1.37

Hahn, C., Evans, G., 2017. Absorption of trace metals in the zinc-deficient rat. Am. J. Physiol. Content 228, 10201023. https://doi.org/10.1152/ajplegacy.1975.228.4.1020

Helsel, D.R., 2011. Statistics for censored environmental data using Minitab® and R. John Wiley \& Sons, Inc., 
Isaksson, C., 2010. Pollution and its impact on wild animals: A meta-analysis on oxidative stress. Ecohealth 7 , 342-350. https://doi.org/10.1007/s10393-010-0345-7

Jaishankar, M., Tseten, T., Anbalagan, N., Mathew, B.B., Beeregowda, K.N., 2014. Toxicity, mechanism and health effects of some heavy metals. Interdiscip. Toxicol. https://doi.org/10.2478/intox-2014-0009

Järup, L., 2003. Hazards of heavy metal contamination. Br. Med. Bull. 68, $167-82$. https://doi.org/10.1093/bmb/ldg032

Koivula, M.J., Eeva, T., 2010. Metal-related oxidative stress in birds. Environ. Pollut. https://doi.org/10.1016/j.envpol.2010.03.013

Koivula, M.J., Kanerva, M., Salminen, J.-P., Nikinmaa, M., Eeva, T., 2011. Metal pollution indirectly increases oxidative stress in great tit (Parus major) nestlings. Environ. Res. 111, 362-370. https://doi.org/10.1016/j.envres.2011.01.005

Komjarova, I., Blust, R., 2009. Effect of $\mathrm{Na}, \mathrm{Ca}$ and $\mathrm{pH}$ on simultaneous uptake of $\mathrm{Cd}, \mathrm{Cu}, \mathrm{Ni}, \mathrm{Pb}$, and $\mathrm{Zn}$ in the water flea Daphnia magna measured using stable isotopes. Aquat. Toxicol. 94, 81-86. https://doi.org/10.1016/j.aquatox.2009.05.018

Kucuk, O., 2008. Zinc in a combination with magnesium helps reducing negative effects of heat stress in quails. Biol. Trace Elem. Res. 123, 144-153. https://doi.org/10.1007/s12011-007-8083-6

Kurhalyuk, N., Hetmański, T., Antonowicz, J., Tkachenko, H., 2009. Oxidative stress and protein oxidation affected by toxic metals in feral pigeons (Columba livia) from northern Poland. Balt. Coast. Zo. 187-197. https://doi.org/DOI 10.1002/ana.410360714

Leonard, S.S., Harris, G.K., Shi, X., 2004. Metal-induced oxidative stress and signal transduction. Free Radic. Biol. Med. https://doi.org/10.1016/j.freeradbiomed.2004.09.010

Levander, O.A., 1978. Metabolic interactions between metals and metalloids. Environ. Health Perspect. VOL. 25, $77-80$.

Lodenius, M., Solonen, T., 2013. The use of feathers of birds of prey as indicators of metal pollution. Ecotoxicology 22, 1319-1334. https://doi.org/10.1007/s10646-013-1128-z

Lucia, M., Andre, J.M., Gonzalez, P., Baudrimont, M., Gontier, K., Maury-Brachet, R., Davail, S., 2009. Impact of cadmium on aquatic bird Cairina moschata. BioMetals 22, 843-853. https://doi.org/10.1007/s10534-0099232-5

Mora, M.A., 2003. Heavy metals and metalloids in egg contents and eggshells of passerine birds from Arizona. Environ. Pollut. 125, 393-400. https://doi.org/10.1016/S0269-7491(03)00108-8

Poulin, R.G., Brigham, R.M., 2001. Effects of supplemental calcium on the growth rate of an insectivorous bird, the purple martin (Progne subis). Ecoscience 8, 151-156. https://doi.org/10.1080/11956860.2001.11682640 
Prasanthi, R.P.J., Devi, C.B., Basha, D.C., Reddy, N.S., Reddy, G.R., 2010. Calcium and zinc supplementation protects lead $(\mathrm{Pb})$-induced perturbations in antioxidant enzymes and lipid peroxidation in developing mouse brain. Int. J. Dev. Neurosci. 28, 161-167. https://doi.org/10.1016/j.ijdevneu.2009.12.002

R Development Core Team, 2016. R: A language and environment for statistical computing. Vienna, Austria.

Rainio, M.J., Eeva, T., Lilley, T., Stauffer, J., Ruuskanen, S., 2015. Effects of early-life lead exposure on oxidative status and phagocytosis activity in great tits (Parus major). Comp. Biochem. Physiol. Part - C Toxicol. Pharmacol. 167, 24-34. https://doi.org/10.1016/j.cbpc.2014.08.004

Rainio, M.J., Kanerva, M., Salminen, J.P., Nikinmaa, M., Eeva, T., 2013. Oxidative status in nestlings of three small passerine species exposed to metal pollution. Sci. Total Environ. 454-455, 466-473. https://doi.org/10.1016/j.scitotenv.2013.03.033

Salmón, P., Nilsson, J.F., Watson, H., Bensch, S., Isaksson, C., 2017. Selective disappearance of great tits with short telomeres in urban areas. Proc. R. Soc. B Biol. Sci. 284. https://doi.org/10.1098/rspb.2017.1349

Sánchez-Virosta, P., Espín, S., Ruiz, S., Salminen, J.P., García-Fernández, A.J., Eeva, T., 2018. Experimental manipulation of dietary arsenic levels in great tit nestlings: Accumulation pattern and effects on growth, survival and plasma biochemistry. Environ. Pollut. 233, 764-773. https://doi.org/10.1016/j.envpol.2017.10.113

Sánchez-Virosta, P., Espín, S., Ruiz, S., Stauffer, J., Kanerva, M., García-Fernández, A.J., Eeva, T., 2019. Effects of calcium supplementation on oxidative status and oxidative damage in great tit nestlings inhabiting a metalpolluted area. Environ. Res. 484-492. https://doi.org/10.1016/j.envres.2019.01.047

Scheuhammer, A.M., 1996. Influence of reduced dietary calcium on the accumulation and effects of lead, cadmium, and aluminum in birds. Environ. Pollut. 94, 337-343. https://doi.org/10.1016/S02697491(96)00084-X

Scheuhammer, A.M., 1991. Effects of acidification on the availability of toxic metals and calcium to wild birds and mammals. Environ. Pollut. 71, 329-375. https://doi.org/10.1016/0269-7491(91)90036-V

Six, K.M., Goyer, R.A., 1970. Experimental enhancement of lead toxicity by low dietary calcium. J. Lab. Clin. Med. 76, 933-942. https://doi.org/10.5555/URI:PII:0022214370902301

Snoeijs, T., Dauwe, T., Pinxten, R., Darras, V.M., Arckens, L., Eens, M., 2005. The combined effect of lead exposure and high or low dietary calcium on health and immunocompetence in the zebra finch (Taeniopygia guttata). Environ. Pollut. 134, 123-132. https://doi.org/10.1016/j.envpol.2004.07.009

Srivastava, D., Subramanian, R.B., Madamwar, D., Flora, S.J.S., 2010. Protective effects of selenium, calcium, and magnesium against arsenic-induced oxidative stress in male rats. Arh. Hig. Rada Toksikol. 61, 153-159. https://doi.org/10.2478/10004-1254-61-2010-1993

Stankevičiūtè, M., Sauliutè, G., Makaras, T., Markuckas, A., Virbickas, T., Baršienė, J., 2018. Responses of biomarkers in Atlantic salmon (Salmo salar) following exposure to environmentally relevant concentrations of complex metal mixture ( $\mathrm{Zn}, \mathrm{Cu}, \mathrm{Ni}, \mathrm{Cr}, \mathrm{Pb}, \mathrm{Cd})$. Part II. Ecotoxicology 27, 1069-1086. 
Stauffer, J., Panda, B., Eeva, T., Rainio, M., Ilmonen, P., 2017. Telomere damage and redox status alterations in free-living passerines exposed to metals. Sci. Total Environ. 575, 841-848. https://doi.org/10.1016/j.scitotenv.2016.09.131

Stohs, S.J., Bagchi, D., 1995. Oxidative mechanisms in the toxicity of metal ions. Free Radic. Biol. Med. https://doi.org/10.1016/0891-5849(94)00159-H

Tully, T.N., Lawton, J.M., Dorrestein, G.M., 2000. Handbook of avian medicine Second Edition, Handbook of

Wah Chu, K., Chow, K.L., 2002. Synergistic toxicity of multiple heavy metals is revealed by a biological assay using a nematode and its transgenic derivative. Aquat. Toxicol. 61, 53-64. https://doi.org/10.1016/S0166445X(02)00017-6

Zuur, A.F., Ieno, E.N., Walker, N.J., Saveleiv, A.A., Smith, G.M., 2009. Mixed effects models and extension in 648

Wang, J., Wang, T., Burken, J.G., Chusuei, C.C., Ban, H., Ladwig, K., Huang, C.P., 2008. Adsorption of arsenic(V) onto fly ash: A speciation-based approach. Chemosphere 72, 381-388. https://doi.org/10.1016/j.chemosphere.2008.02.045

Yenice, E., Mizrak, C., Gültekin, M., Atik, Z., Tunca, M., 2015. Effects of dietary organic or inorganic manganese, zinc, copper and chrome supplementation on the performance, egg quality and hatching characteristics of laying breeder hens. Ankara Üniv Vet Fak Derg 62, 63-68.

Zann, R., 1996. Zebra finch: a synthesis of field and laboratory studies, Zebra Finch: A Synthesis of Field and Laboratory Studies. Oxford University Press.

Zhu, Y., Wang, J., Bai, Y., Zhang, R., 2004. Cadmium, Chromium, and Copper induce polychromatocyte micronuclei in carp (Cyprinus carpio L. ). Bull. Environ. Contam. Toxicol. 72, 78-86. https://doi.org/10.1007/s00128-003-0243-6 ecology with R, First Edit. ed. Springer. https://doi.org/10.1017/CBO9781107415324.004 


\begin{tabular}{|c|c|c|c|c|c|c|c|c|c|c|c|c|c|c|c|c|}
\hline \multirow[b]{2}{*}{ Metal } & \multirow[b]{2}{*}{ Treatment } & \multicolumn{2}{|r|}{ T0 } & & \multicolumn{3}{|c|}{$\mathrm{T} 14$} & \multicolumn{3}{|c|}{ T29 } & \multicolumn{3}{|c|}{ T43 } & \multicolumn{3}{|c|}{ T57 } \\
\hline & & $>\mathrm{LOD} / \mathrm{n}$ & mean \pm SD & & $>\mathrm{LOD} / \mathrm{n}$ & mean \pm SD & & $>\mathrm{LOD} / \mathrm{n}$ & mean \pm SD & & $>\mathrm{LOD} / \mathrm{n}$ & mean \pm SD & & $>\mathrm{LOD} / \mathrm{n}$ & mean \pm SD & \\
\hline \multirow[t]{4}{*}{ Arsenic } & Ctrl & $0 / 9$ & & $a$ & $1 / 9$ & 0.007 & $a$ & $1 / 9$ & 0.003 & $a$ & $1 / 9$ & 0.002 & $a$ & $0 / 9$ & & $a$ \\
\hline & TME & $0 / 8$ & & $a$ & $10 / 10$ & $0.016 \pm 0.009$ & $b$ & $9 / 9$ & $0.014 \pm 0.008$ & $b$ & $10 / 10$ & $0.021 \pm 0.011$ & $b$ & $10 / 10$ & $0.018 \pm 0.011$ & $b$ \\
\hline & $\mathrm{Ca}$ & $0 / 9$ & & $a$ & $0 / 9$ & & $a$ & $3 / 9$ & $0.004 \pm 0.003$ & $a$ & $1 / 9$ & 0.005 & $a$ & $0 / 9$ & & $a$ \\
\hline & $\mathrm{TME}+\mathrm{Ca}$ & $2 / 7$ & $0.012 \pm 0.002$ & $a$ & $7 / 9$ & $0.004 \pm 0.002$ & $a$ & $0 / 9$ & & $a$ & $4 / 9$ & $0.008 \pm 0.002$ & $a$ & $9 / 9$ & $0.004 \pm 0.003$ & $a$ \\
\hline \multirow[t]{4}{*}{ Cadmium } & Ctrl & $0 / 9$ & & & $0 / 9$ & & & $0 / 9$ & & $a$ & $2 / 9$ & $\begin{array}{c}0.01 \pm 0.002 \\
0.002\end{array}$ & $a b$ & $0 / 9$ & & \\
\hline & TME & $0 / 8$ & & & $0 / 10$ & & & $4 / 9$ & $0.005 \pm 0,0006$ & $a b$ & $2 / 10$ & \pm 0.00005 & $a$ & $2 / 10$ & $0.005 \pm 0.0003$ & \\
\hline & $\mathrm{Ca}$ & $1 / 9$ & 0.007 & & $0 / 9$ & & & $0 / 9$ & & $a$ & $1 / 9$ & 0.009 & $b$ & $1 / 9$ & 0.068 & \\
\hline & $\mathrm{TME}+\mathrm{Ca}$ & $1 / 7$ & 0.23 & & $3 / 9$ & $0.005 \pm 0.003$ & & $9 / 9$ & $0.007 \pm 0.001$ & $b$ & $1 / 9$ & 0.004 & $a$ & $0 / 9$ & & \\
\hline \multirow[t]{4}{*}{ Chromium } & Ctrl & $5 / 9$ & $0.006 \pm 0.007$ & & $6 / 9$ & $0.011 \pm 0.006$ & & $4 / 9$ & $0.106 \pm 0.331$ & & $2 / 9$ & $0.014 \pm 0.012$ & & $2 / 9$ & 0.014 & \\
\hline & TME & $1 / 8$ & 0.002 & & $1 / 10$ & 0.029 & & $1 / 9$ & 0.156 & & $2 / 10$ & $0.02 \pm 0.012$ & & $2 / 10$ & 0.020 & \\
\hline & $\mathrm{Ca}$ & $4 / 9$ & $0.013 \pm 0.032$ & & $6 / 9$ & $0.013 \pm 0.022$ & & $4 / 9$ & $0.006 \pm 0.003$ & & $2 / 9$ & $0.032 \pm 0.019$ & & $2 / 9$ & 0.032 & \\
\hline & $\mathrm{TME}+\mathrm{Ca}$ & $1 / 7$ & 0.011 & & $1 / 9$ & 0.012 & & $0 / 9$ & & & $1 / 9$ & 0.027 & & $1 / 9$ & 0.027 & \\
\hline \multirow[t]{4}{*}{ Cobalt } & Ctrl & $0 / 9$ & & & $0 / 9$ & & & $3 / 9$ & $0.003 \pm 0.004$ & & $1 / 9$ & 0.002 & & $0 / 9$ & & \\
\hline & TME & $0 / 8$ & & & $0 / 10$ & & & $0 / 9$ & & & $5 / 10$ & $0.003 \pm 0.003$ & & $6 / 10$ & $0.003 \pm 0.001$ & \\
\hline & $\mathrm{Ca}$ & $0 / 9$ & & & $0 / 9$ & & & $2 / 9$ & $0.003 \pm 0.003$ & & $1 / 9$ & 0.002 & & $0 / 9$ & & \\
\hline & $\mathrm{TME}+\mathrm{Ca}$ & $0 / 7$ & & & $0 / 9$ & & & 0/9 & & & $4 / 9$ & $0.034 \pm 0.105$ & & $3 / 9$ & $0.004 \pm 0.002$ & \\
\hline \multirow[t]{4}{*}{ Copper } & Ctrl & $9 / 9$ & $0.52 \pm 0.441$ & & $9 / 9$ & $0.398 \pm 0.167$ & & $9 / 9$ & $0.292 \pm 0.337$ & $a$ & $9 / 9$ & $0.245 \pm 0.037$ & $a$ & $9 / 9$ & $0.32 \pm 0.061$ & $a$ \\
\hline & TME & $8 / 8$ & $0.296 \pm 0.048$ & & $10 / 10$ & $0.283 \pm 0.088$ & & $9 / 9$ & $0.34 \pm 0.121$ & $a$ & $10 / 10$ & $0.326 \pm 0.091$ & $a b$ & $10 / 10$ & $0.239 \pm 0.062$ & $a$ \\
\hline & $\mathrm{Ca}$ & $9 / 9$ & $0.364 \pm 0.149$ & & $9 / 9$ & $0.355 \pm 0.074$ & & $9 / 9$ & $0.552 \pm 1.206$ & $a$ & $9 / 9$ & $0.274 \pm 0.077$ & $a b$ & $9 / 9$ & $0.326 \pm 0.053$ & $a$ \\
\hline & $\mathrm{TME}+\mathrm{Ca}$ & $7 / 7$ & $0.325 \pm 0.147$ & & $9 / 9$ & $0.403 \pm 0.153$ & & $9 / 9$ & $0.358 \pm 0.146$ & $a$ & $9 / 9$ & $0.326 \pm 0.052$ & $b$ & $9 / 9$ & $0.286 \pm 0.03$ & $a$ \\
\hline \multirow[t]{4}{*}{ Lead } & Ctrl & $4 / 9$ & $0.031 \pm 0.043$ & & $5 / 9$ & $0.034 \pm 0.043$ & $a$ & $5 / 9$ & $0.016 \pm 0.007$ & $a$ & $9 / 9$ & $0.076 \pm 0.131$ & $a$ & $2 / 9$ & $0.04 \pm 0.032$ & $a c$ \\
\hline & TME & $0 / 8$ & & & $10 / 10$ & $0.2 \pm 0.063$ & $b$ & $9 / 9$ & $0.218 \pm 0.084$ & $b$ & $10 / 10$ & $0.276 \pm 0.105$ & $b$ & $10 / 10$ & $0.226 \pm 0.089$ & $b$ \\
\hline & $\mathrm{Ca}$ & $3 / 9$ & $0.055 \pm 0.17$ & & $8 / 9$ & $0.024 \pm 0.01$ & $a$ & $2 / 9$ & 0.006 & $a$ & $9 / 9$ & $0.032 \pm 0.054$ & $a$ & $1 / 9$ & 0.240 & $c$ \\
\hline & $\mathrm{TME}+\mathrm{Ca}$ & $2 / 7$ & $0.186 \pm 0.453$ & & $6 / 9$ & $0.093 \pm 0.043$ & $a b$ & $6 / 9$ & $0.055 \pm 0.026$ & $a$ & $9 / 9$ & $0.057 \pm 0.024$ & $a$ & $9 / 9$ & $0.064 \pm 0.036$ & $a$ \\
\hline \multirow[t]{4}{*}{ Nickel } & Ctrl & $2 / 9$ & $0.024 \pm 0.013$ & & $9 / 9$ & $0.01 \pm 0.005$ & & $6 / 9$ & $0.028 \pm 0.03$ & $a$ & $3 / 9$ & 0.004 & & $0 / 9$ & & \\
\hline & TME & $2 / 8$ & $0.001 \pm 0.005$ & & $1 / 10$ & 0.184 & & $1 / 9$ & 0.013 & $a$ & $0 / 10$ & & & $0 / 10$ & & \\
\hline & $\mathrm{Ca}$ & $3 / 9$ & $0.007 \pm 0.002$ & & $8 / 9$ & $0.009 \pm 0.003$ & & $6 / 9$ & $0.156 \pm 0.419$ & $a$ & $1 / 9$ & 0.012 & & $0 / 9$ & & \\
\hline & $\mathrm{TME}+\mathrm{Ca}$ & $1 / 7$ & 0.015 & & $2 / 9$ & $0.059 \pm 0.133$ & & $2 / 9$ & $0.01 \pm 0.003$ & $a$ & $0 / 9$ & & & $0 / 9$ & & \\
\hline Zinc & Ctrl & $9 / 9$ & $4.448 \pm 1.338$ & & $9 / 9$ & $5.7 \pm 2.909$ & & $9 / 9$ & $2.401 \pm 0.54$ & $a$ & $9 / 9$ & $3.789 \pm 0.45$ & $a$ & $9 / 9$ & $3.649 \pm 1.036$ & \\
\hline
\end{tabular}




\begin{tabular}{|c|c|c|c|c|c|c|c|c|c|c|c|c|}
\hline TME & $8 / 8$ & $4.415 \pm 1.135$ & $10 / 10$ & $4.136 \pm 0.916$ & 9/9 & $3.41 \pm 0.519$ & $a b$ & $10 / 10$ & $4.508 \pm 0.428$ & $a b$ & $10 / 10$ & $3.722 \pm 0.695$ \\
\hline $\mathrm{Ca}$ & 9/9 & $4.89 \pm 2.018$ & 9/9 & $5.124 \pm 1.04$ & 9/9 & $2.683 \pm 0.525$ & $c$ & 9/9 & $4.38 \pm 0.495$ & $b$ & 9/9 & $4.164 \pm 1.164$ \\
\hline $\mathrm{TME}+\mathrm{Ca}$ & $7 / 7$ & $4.645 \pm 1.413$ & $9 / 9$ & $4.25 \pm 1.049$ & 9/9 & $3.42 \pm 0.617$ & bc & 9/9 & $4.491 \pm 0.8$ & $a b$ & 9/9 & $5.184 \pm 2.868$ \\
\hline
\end{tabular}

low-Ca diet and no TME, 'TME' = birds with low-Ca diet exposed to a TME cocktail, 'Ca'= rich-Ca diet and no TME and 'TME+Ca'= rich-Ca diet and TME cocktail. Post-hoc tests were performed when differences between treatments were significant (Table 2). Different letters represent significant differences using the Bonferroni correction ( $\mathrm{p}<0.0083$ ) and are represented in bold. The absence of letter indicates that differences between treatments were not significant. 
Table 2. Results of statistical models comparing metal concentration in blood between treatments at different times (from 0 to 57 days) (Generalized Wilcoxon tests)

\begin{tabular}{|c|c|c|c|c|c|c|c|c|c|c|}
\hline & \multicolumn{2}{|c|}{ TO } & \multicolumn{2}{|c|}{$\mathrm{T} 14$} & \multicolumn{2}{|c|}{ T29 } & \multicolumn{2}{|c|}{$\mathrm{T} 43$} & \multicolumn{2}{|c|}{ T57 } \\
\hline & $\mathbf{X}^{2}$ & $p$ & $\mathbf{X}^{2}$ & $p$ & $\mathbf{X}^{2}$ & $p$ & $x^{2}$ & $p$ & $\mathbf{X}^{2}$ & $p$ \\
\hline Arsenic & 8 & 0.05 & 43.8 & $<0.001$ & 44.1 & $<0.001$ & 47.9 & $<0.001$ & 40.6 & $<0.001$ \\
\hline Cadmium & 2.3 & 0.5 & 2.4 & 0.1 & 27.8 & $<0.001$ & 8.9 & 0.03 & 4.6 & 0.2 \\
\hline Chromium & 4.8 & 0.2 & 1.1 & 0.8 & 4.2 & 0.2 & 0.6 & 0.9 & \multicolumn{2}{|c|}{ not detected } \\
\hline Copper & 2.2 & 0.5 & 4.7 & 0.2 & 18 & $<0.001$ & 9.5 & 0.02 & 9.8 & $<0.001$ \\
\hline Lead & 3.8 & 0.3 & 39.7 & $<0.001$ & 50.3 & $<0.001$ & 39.2 & $<0.001$ & 40.3 & $<0.001$ \\
\hline Nickel & 1.1 & 0.8 & 1.5 & 0.7 & 12 & 0.007 & 2.2 & 0.5 & \multicolumn{2}{|c|}{ not detected } \\
\hline Zinc & 0.4 & 0.9 & 4.5 & 0.2 & 16.9 & $<0.001$ & 8.1 & 0.04 & 5.1 & 0.2 \\
\hline
\end{tabular}

Notes : Significant differences between treatments are represented in bold.

654

Table 3. Effects of treatment and exposure time on PCA component (mixed linear models and type III ANOVAs).

\begin{tabular}{ccccc}
\hline & Variable & F-value & DF & p-value \\
\hline \hline PC1Feather & Treatment $^{\star}$ Exposure time & 27.53 & 3,33 & $<\mathbf{0 . 0 0 1}$ \\
& Treatment & 9.85 & 3,33 & $<\mathbf{0 . 0 0 1}$ \\
& Exposure time $^{\star}$ & 66.07 & 1,33 & $<\mathbf{0 . 0 0 1}$ \\
\hline PC2Feather & Treatment $^{\star}$ Exposure time & 17.06 & 3,33 & $<\mathbf{0 . 0 0 1}$ \\
& Treatment & 4.95 & 3,33 & $\mathbf{0 . 0 0 6 0}$ \\
& Exposure time & 12.40 & 1,33 & $\mathbf{0 . 0 0 1 3}$ \\
\hline
\end{tabular}

Full models included treatment ('Ctrl': control group with low-Ca diet and no TME, 'TME': birds with low-Ca diet exposed to a TME cocktail, 'Ca':rich-Ca diet and no TME and 'TME+Ca': rich-Ca diet and TME cocktail), exposure time (T0 and T29) and the interaction term. In each model, bird ID was the random factor. Significant variables are represented in bold. Post-hoc tests are in Table A.4. 
Table 4. Physiological parameters and body mass depending on A) treatment, exposure time and interaction term and B) composite variables of metal concentration from the PCA: PCAfeather1 and PCAfeather2.

Variable

F-value

DF p-value

\section{A) Models with treatment groups and exposure time}

\begin{tabular}{|c|c|c|c|c|}
\hline RTL (log) & Exposure time & 3.07 & 2,72 & 0.052 \\
\hline Body mass & Treatment & 1.38 & 3,32 & 0.26 \\
\hline ROMs & Exposure time & 8.83 & 2,69 & $<0.001$ \\
\hline GSHtot $(\log )$ & Exposure time & 7.81 & 2,72 & 0.001 \\
\hline \multirow[t]{3}{*}{ GSH (log) } & Treatment ${ }^{\star}$ Exposure time & 2.27 & 6,66 & 0.047 \\
\hline & Treatment & 2.21 & 3,33 & 0.106 \\
\hline & Exposure time & 1.37 & 2,66 & 0.262 \\
\hline GSSG (log) & Exposure time & 9.43 & 2,72 & $<0.001$ \\
\hline \multirow[t]{3}{*}{ GPx (log) } & Treatment ${ }^{\star}$ Exposure time & 3.71 & 6,66 & 0.003 \\
\hline & Treatment & 1.75 & 3,33 & 0.175 \\
\hline & Exposure time & 2.17 & 2,66 & 0.122 \\
\hline \multicolumn{5}{|c|}{ B) Models with PCA composite variables of metal concentration } \\
\hline \multirow[t]{2}{*}{ RTL (log) } & PC1Feather & 1.082 & 1,35 & 0.305 \\
\hline & PC2Feather & 4.226 & 1,35 & 0.047 \\
\hline \multirow[t]{2}{*}{ Body mass } & PC1Feather & 0.34 & 1,35 & 0.561 \\
\hline & PC2Feather & 0.002 & 1,35 & 0.961 \\
\hline \multirow[t]{2}{*}{ ROMs (log) } & PC1Feather & 0.0002 & 1,33 & 0.99 \\
\hline & PC2Feather & 0.933 & 1,33 & 0.34 \\
\hline \multirow[t]{2}{*}{ GSH (log) } & PC1Feather & 0.298 & 1,35 & 0.588 \\
\hline & PC2Feather & 0.370 & 1,35 & 0.547 \\
\hline \multirow[t]{2}{*}{ GSSG (log) } & PC1Feather & 0.077 & 1,35 & 0.783 \\
\hline & PC2Feather & 0.463 & 1,35 & 0.500 \\
\hline \multirow[t]{2}{*}{ GSHtot $(\log )$} & PC1Feather & 0.393 & 1,35 & 0.534 \\
\hline & PC2Feather & 0.774 & 1,35 & 0.384 \\
\hline \multirow[t]{2}{*}{ GPx (log) } & PC1Feather & 0.01 & 1,35 & 0.929 \\
\hline & PC2Feather & 1.19 & 1,35 & 0.284 \\
\hline
\end{tabular}

Note : RTL= Relative telomere length (ratio copy telomere/ copy control gene); $\mathrm{ROMs}=$ Reactive oxygene metabolites ; $\mathrm{GSSG}=$ oxidised glutathione; $\mathrm{GSH}=$ free glutathione $\mathrm{GSH}$ tot = total glutathione; $\mathrm{GPx}=$ glutathione peroxidase. Best models were selected with a stepwise procedure from the full model that included treatment. In each model (A and B), bird ID was the random factor. The significant results are in bold. 
Table 5. Means and standard deviation of body mass and physiological parameters in the different treatments at 669 different exposure times (day 0, day 29, and day 57).

\begin{tabular}{|c|c|c|c|c|c|c|c|c|}
\hline & & RTL & Body mass & ROM & GSH & GSSG & GSHtot & GPx \\
\hline & Treatment & Mean $\pm s d$ & Mean \pm sd & Mean $\pm s d$ & Mean \pm sd & Mean $\pm s d$ & Mean \pm sd & Mean $\pm s d$ \\
\hline \multirow[t]{4}{*}{ TO } & Ctrl & $0.65 \pm 0.24$ & $17.77 \pm 2.25$ & $\begin{array}{c}4.18 \pm \\
2.14\end{array}$ & $\begin{array}{c}674.97 \pm \\
954.56\end{array}$ & $\begin{array}{c}543.14 \pm \\
846.82\end{array}$ & $\begin{array}{c}1761.26 \pm \\
2323.36\end{array}$ & $\begin{array}{c}792.22 \pm \\
160.96\end{array}$ \\
\hline & TME & $0.75 \pm 0.26$ & $16.38 \pm 1.84$ & $\begin{array}{c}3.96 \pm \\
1.62\end{array}$ & $\begin{array}{c}188.24 \pm \\
164.33\end{array}$ & $\begin{array}{c}143.77 \pm \\
135.06\end{array}$ & $\begin{array}{l}475.8 \pm \\
400.32\end{array}$ & $\begin{array}{c}723.96 \pm \\
162.07\end{array}$ \\
\hline & $\mathrm{Ca}$ & $0.7 \pm 0.17$ & $16.18 \pm 2.39$ & $\begin{array}{c}4.86 \pm \\
2.77\end{array}$ & $\begin{array}{c}271.48 \pm \\
446.11\end{array}$ & $\begin{array}{c}254.34 \pm \\
332.75\end{array}$ & $\begin{array}{l}780.19 \pm \\
1095.95\end{array}$ & $\begin{array}{c}839.71 \pm \\
211.61\end{array}$ \\
\hline & $\mathrm{TME}+\mathrm{Ca}$ & $0.76 \pm 0.18$ & $17.23 \pm 2$ & $4.54 \pm 3.7$ & $\begin{array}{c}401.01 \pm \\
426.13\end{array}$ & $\begin{array}{c}96.72 \pm \\
111.61\end{array}$ & $\begin{array}{c}594.46 \pm \\
573.27\end{array}$ & $\begin{array}{c}683.71 \pm \\
134.05\end{array}$ \\
\hline \multirow[t]{4}{*}{ T29 } & Ctrl & $0.85 \pm 0.38$ & $18.91 \pm 2.41$ & $\begin{array}{c}3.74 \pm \\
2.17\end{array}$ & $\begin{array}{c}377.18 \pm \\
260.39\end{array}$ & $\begin{array}{c}226.44 \pm \\
203.9\end{array}$ & $\begin{array}{c}830.05 \pm \\
591.91\end{array}$ & $\begin{array}{c}741.76 \pm \\
90.32\end{array}$ \\
\hline & TME & $0.75 \pm 0.22$ & $16.85 \pm 1.74$ & $\begin{array}{c}5.74 \pm \\
4.61\end{array}$ & $\begin{array}{c}349.96 \pm \\
276.77\end{array}$ & $\begin{array}{c}218.16 \pm \\
303.68\end{array}$ & $\begin{array}{c}786.27 \pm \\
828.51\end{array}$ & $\begin{array}{c}656.53 \pm \\
82.16\end{array}$ \\
\hline & $\mathrm{Ca}$ & $0.9 \pm 0.31$ & $16.56 \pm 2.35$ & $\begin{array}{c}5.31 \pm \\
1.85\end{array}$ & $\begin{array}{l}647.6 \pm \\
765.06\end{array}$ & $\begin{array}{c}296.06 \pm \\
469.21\end{array}$ & $\begin{array}{c}1239.73 \pm \\
1623.15\end{array}$ & $\begin{array}{c}636.84 \pm \\
122.88\end{array}$ \\
\hline & $\mathrm{TME}+\mathrm{Ca}$ & $1 \pm 0.47$ & $17.09 \pm 1.93$ & $\begin{array}{c}3.82 \pm \\
1.05\end{array}$ & $\begin{array}{c}197.44 \pm \\
163.56\end{array}$ & $\begin{array}{c}98.16 \pm \\
82.93\end{array}$ & $\begin{array}{c}393.73 \pm \\
237.16\end{array}$ & $\begin{array}{c}782.08 \pm \\
133.01\end{array}$ \\
\hline \multirow[t]{4}{*}{ T57 } & Ctrl & $0.63 \pm 0.24$ & $17.96 \pm 2.01$ & $\begin{array}{c}2.18 \pm \\
1.41\end{array}$ & $\begin{array}{c}372.11 \pm \\
665.34\end{array}$ & $\begin{array}{l}572.6 \pm \\
584.78\end{array}$ & $\begin{array}{c}1517.33 \pm \\
1679.75\end{array}$ & $\begin{array}{c}684.44 \pm \\
149.96\end{array}$ \\
\hline & TME & $0.7 \pm 0.19$ & $17.01 \pm 1.73$ & $\begin{array}{c}3.86 \pm \\
2.38\end{array}$ & $\begin{array}{c}569.06 \pm \\
691.44\end{array}$ & $\begin{array}{c}383.31 \pm \\
299.51\end{array}$ & $\begin{array}{c}1335.67 \pm \\
663.81\end{array}$ & $\begin{array}{c}759.95 \pm \\
192.36\end{array}$ \\
\hline & $\mathrm{Ca}$ & $0.85 \pm 0.2$ & $16.09 \pm 1.88$ & $3.1 \pm 1.67$ & $\begin{array}{c}729.12 \pm \\
897.1\end{array}$ & $\begin{array}{c}883.29 \pm \\
893.29\end{array}$ & $\begin{array}{c}2495.69 \pm \\
2507.2\end{array}$ & $\begin{array}{l}775.7 \pm \\
237.53\end{array}$ \\
\hline & $\mathrm{TME}+\mathrm{Ca}$ & $0.71 \pm 0.26$ & $17.14 \pm 2.23$ & $\begin{array}{l}3.68 \pm \\
2.25\end{array}$ & $\begin{array}{c}369.31 \pm \\
427.55\end{array}$ & $\begin{array}{c}436.67 \pm \\
473.45\end{array}$ & $\begin{array}{c}1242.63 \pm \\
1284.69\end{array}$ & $\begin{array}{c}691.85 \pm \\
102.07\end{array}$ \\
\hline
\end{tabular}

Notes :'Ctrl'= control group with low-Ca diet and no TME; 'TME' = birds with low-Ca diet exposed to a TME cocktail; 'Ca'=rich-Ca diet and no TME; 'TME+Ca'= rich-Ca diet and TME cocktail; $\mathrm{RTL}=$ Relative telomere length (copy telomere /copy control gene); body mass (g); ROM= Reactive oxygene metabolites (mg H2O2/dl);GSH = free glutathione $(\mu \mathrm{M})$; GSSG= oxidised glutathione $(\mu \mathrm{M})$; GSHtot= total glutathione $(\mu \mathrm{M}) ; \mathrm{GPX}=$ glutathione peroxidase $(\mathrm{U} / \mathrm{L}$ hemolysat $)$ 
Table 6. Physiological parameters and body mass depending on each single metal concentration in blood (mixed linear models, type III ANOVAs).

674

\begin{tabular}{|c|c|c|c|c|c|c|c|c|}
\hline & & RTL (log) & $\begin{array}{l}\text { Body } \\
\text { mass }\end{array}$ & ROM (log) & GSH (log) & $\begin{array}{c}\text { GSSG } \\
(\log )\end{array}$ & $\begin{array}{c}\text { GSHtot } \\
(\log ) \\
\end{array}$ & GPx(log) \\
\hline Arsenic & Fvalue(df) & $1.53(1,10)$ & $0.83(1,10)$ & $1.35(1,9)$ & $1.67(1,10)$ & $3.95(1,10)$ & $0.13(1,22)$ & $0.22(1,10)$ \\
\hline$n=34$ & $p$-value & 0.24 & 0.38 & 0.27 & 0.23 & 0.08 & 0.73 & 0.65 \\
\hline Chromium & Fvalue(df) & $0.36(1,5)$ & $0.93(1,5)$ & $3.49(1,5)$ & $0.01(1,5)$ & $3.32(1,5)$ & $0.43(1,5)$ & $0.02(1,5)$ \\
\hline $\mathrm{n}=20$ & $\mathrm{p}$-value & 0.58 & 0.38 & 0.12 & 0.94 & 0.13 & 0.54 & 0.88 \\
\hline Copper & Fvalue(df) & $2.92(1,68)$ & $0.2(1,68)$ & $3.66(1,65)$ & $1.67(1,68)$ & $0.21(1,68)$ & $1.12(1,68)$ & $0.6(1,68)$ \\
\hline$n=106$ & $\mathrm{p}$-value & 0.09 & 0.65 & 0.06 & 0.20 & 0.65 & 0.29 & 0.44 \\
\hline Nickel & Fvalue(df) & $4.37(1,5)$ & $0.05(1,5)$ & $0.32(1,5)$ & $0.01(1,5)$ & $1.71(1,5)$ & $1(1,5)$ & $0.01(1,5)$ \\
\hline$n=23$ & $p$-value & 0.09 & 0.84 & 0.60 & 0.91 & 0.25 & 0.36 & 0.91 \\
\hline Lead & Fvalue(df) & $1.68(1,22)$ & $0.21(1,22)$ & $0.2(1,21)$ & $1.77(1,22)$ & $0.38(1,22)$ & $1.27(1,22)$ & $0.16(1,22)$ \\
\hline$n=53$ & $\mathrm{p}$-value & 0.21 & 0.65 & 0.66 & 0.20 & 0.54 & 0.27 & 0.69 \\
\hline Zinc & Fvalue(df) & $0.31(1,68)$ & $2.3(1,68)$ & $0.19(1,65)$ & $3.93(1,68)$ & $0.53(1,68)$ & $0.56(1,68)$ & $1.59(1,68)$ \\
\hline$n=106$ & $\mathrm{p}$-value & 0.58 & 0.13 & 0.67 & 0.05 & 0.47 & 0.46 & 0.21 \\
\hline Cadmium & Fvalue(df) & $0.05(1,1)$ & $0.93(1,1)$ & $0.02(1,1)$ & No normal & $34.73(1,1)$ & $97.33(1,1)$ & $0.23(1,1)$ \\
\hline $\mathrm{n}=18$ & p-value & 0.86 & 0.51 & 0.91 & & 0.11 & 0.06 & 0.72 \\
\hline
\end{tabular}

Note : ROMs= Reactive oxygene metabolites ; $\mathrm{GSSG}=$ oxidised glutathione; $\mathrm{GSH}=$ free glutathione $\mathrm{GSH}$ tot =glutathione total; $\mathrm{GPx}=$ glutathione peroxidase; $\mathrm{RTL}=$ Relative telomere length (copy telomere/ copy control gene ratio)

In each model, bird ID was the random factor. ' $n$ ' corresponds to the number of observations for each metal. The exposure time was T0, 29 and 57 for physiological parameters and T0, 29, 14, 43 and 57 for body mass 
Fig. 1. Representation of the PCA analysis of metal concentrations in feathers. Empty shapes represent mean coordinates of metal concentration in initial feather (day 0) for each treatment ('Ctrl': control group with low-Ca diet and no TME, 'TME': birds with low-Ca diet exposed to a TME cocktail, 'Ca': rich-Ca diet and no TME and

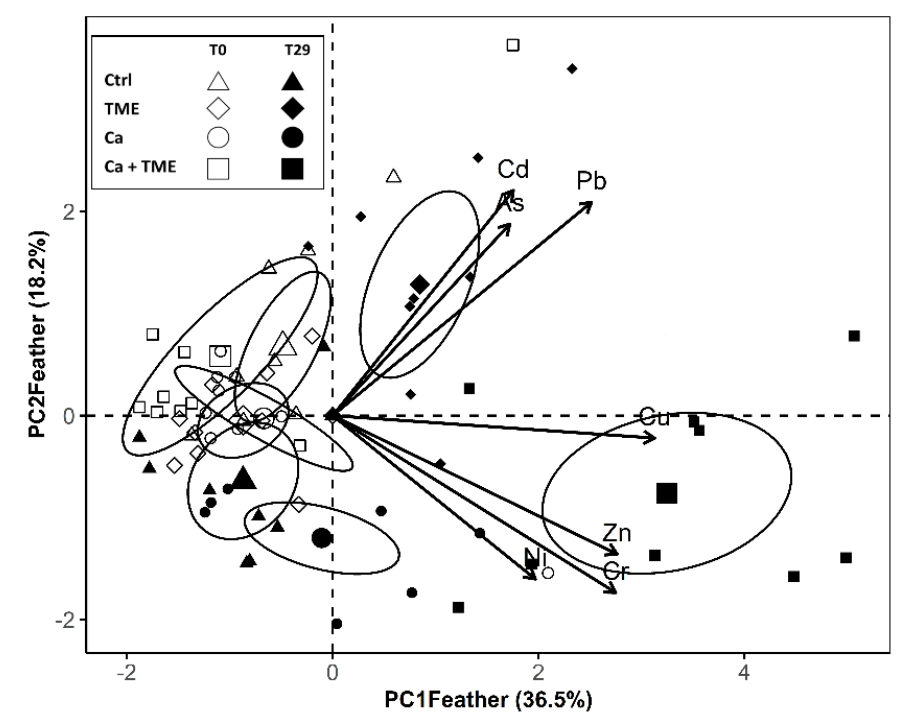

